\title{
Sources of carbonaceous aerosols and deposited black carbon in the Arctic in winter-spring: implications for radiative forcing
}

\author{
Q. Wang ${ }^{1}$, D. J. Jacob ${ }^{1}$, J. A. Fisher ${ }^{1}$, J. Mao ${ }^{1, *}$, E. M. Leibensperger ${ }^{1, * *}$, C. C. Carouge ${ }^{1, * * *}$, P. Le Sager ${ }^{1, * * * *}$, \\ Y. Kondo ${ }^{2}$, J. L. Jimenez ${ }^{3}$, M. J. Cubison ${ }^{3}$, and S. J. Doherty ${ }^{4}$ \\ ${ }^{1}$ School of Engineering and Applied Sciences and Department of Earth and Planetary Sciences, Harvard University, \\ Cambridge, Massachusetts, USA \\ ${ }^{2}$ Department of Earth and Planetary Science, Graduate school of Science, University of Tokyo, Tokyo, Japan \\ ${ }^{3}$ Cooperative Institute for Research in the Environmental Sciences and Department of Chemistry and Biochemistry, \\ University of Colorado, Boulder, Colorado, USA \\ ${ }^{4}$ Joint Institute for the Study of Atmosphere and Ocean, 3737 Brooklyn Ave NE, Seattle, Washington, USA \\ *now at: Atmospheric and Oceanic Sciences, Princeton University, Princeton, New Jersey, USA \\ ** now at: Department of Earth Atmospheric and Planetary Sciences, Massachusetts Institute of Technology, Cambridge, \\ Massachusetts, USA \\ **** now at: University of New South Wales, Sydney, New South Wales, Australia \\ ***** now at: Royal Netherlands Meteorological Institute, De Bilt, The Netherlands
}

Received: 22 June 2011 - Published in Atmos. Chem. Phys. Discuss.: 6 July 2011

Revised: 28 November 2011 - Accepted: 29 November 2011 - Published: 13 December 2011

\begin{abstract}
We use a global chemical transport model (GEOSChem CTM) to interpret observations of black carbon (BC) and organic aerosol (OA) from the NASA ARCTAS aircraft campaign over the North American Arctic in April 2008, as well as longer-term records in surface air and in snow (20072009). BC emission inventories for North America, Europe, and Asia in the model are tested by comparison with surface air observations over these source regions. Russian open fires were the dominant source of $\mathrm{OA}$ in the Arctic troposphere during ARCTAS but we find that $\mathrm{BC}$ was of prevailingly anthropogenic (fossil fuel and biofuel) origin, particularly in surface air. This source attribution is confirmed by correlation of $\mathrm{BC}$ and $\mathrm{OA}$ with acetonitrile and sulfate in the model and in the observations. Asian emissions are the main anthropogenic source of $\mathrm{BC}$ in the free troposphere but European, Russian and North American sources are also important in surface air. Russian anthropogenic emissions appear to dominate the source of BC in Arctic surface air in winter. Model simulations for 2007-2009 (to account for interannual variability of fires) show much higher BC snow content in the Eurasian than the North American Arctic, consistent with the limited observations. We find that anthropogenic sources
\end{abstract}

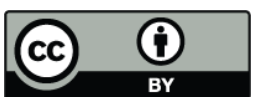

Correspondence to: Q. Wang (wang2@fas.harvard.edu) contribute $90 \%$ of BC deposited to Arctic snow in JanuaryMarch and 60\% in April-May 2007-2009. The mean decrease in Arctic snow albedo from $\mathrm{BC}$ deposition is estimated to be $0.6 \%$ in spring, resulting in a regional surface radiative forcing consistent with previous estimates.

\section{Introduction}

Aerosol pollution in the Arctic peaks in winter-spring, when transport from mid-latitudes is most intense and removal by deposition is slow (Barrie et al., 1981; Quinn et al., 2002, 2007; Law and Stohl, 2007). The principal submicron aerosol components are sulfate and organic aerosols (OA) (Ricard et al., 2002; Zhang et al., 2007), which affect Arctic climate by scattering solar radiation and modifying cloud properties (Kristjansson et al., 2005; Koch et al., 2007; Quinn et al., 2007, 2008). Black carbon (BC) is only a minor contributor to aerosol mass but is of great climatic interest as an absorber of solar radiation both in the atmosphere (Jacobson, 2001; Koch et al., 2007; Quinn et al., 2008) and after deposition to snow (Warren and Wiscombe, 1985; Flanner et al., 2007; McConnell et al., 2007; Quinn et al., 2008). Here we use a global chemical transport model (GEOS-Chem CTM) to interpret aircraft observations of $\mathrm{BC}$ and $\mathrm{OA}$ from the NASA ARCTAS campaign over the North American Arctic

Published by Copernicus Publications on behalf of the European Geosciences Union. 
in April 2008 (Jacob et al., 2010), as well as longer-term records of BC observations at surface sites and in snow. Our goal is to better understand the factors controlling the concentrations of carbonaceous aerosols in the Arctic, the deposition of BC to snow, and the implications for snow albedo and associated radiative forcing.

Observations of elevated BC at Arctic surface sites have been reported since the early 1980s (Rosen et al., 1981; Schnell, 1984; Hansen et al., 1989). The early observations were attributed to fossil fuel combustion in northern Europe and Russia, based on air flow back-trajectories and correlations with trace metal tracers (Shaw, 1982; Djupstrom et al., 1993). BC concentrations in the Arctic decreased from the 1980 s to 2000 , followed by a slight increase in the past decade (Sharma et al., 2006; Eleftheriadis et al., 2009; Gong et al., 2010; Hirdman et al., 2010). Recent measurements of $\mathrm{BC}$ in Arctic snow show a strong association with biomass burning based on tracer correlations and optical properties (Hegg et al., 2009; Doherty et al., 2010; Hegg et al., 2010). Stohl et al. (2007) reported an event of extremely high BC concentrations in the Arctic in spring associated with agricultural burning in Eastern Europe.

The origin of OA in the Arctic has received far less attention. A two-year record of OA concentrations in northern Finland shows a minimum in winter and a maximum in summer attributed to biogenic and photochemical sources (Ricard et al., 2002). Measurements at Barrow show maximum $\mathrm{OA}$ in winter-spring, and correlations with chemical tracers suggest a dominance of ocean emissions (winter) and combustion sources (spring) (Shaw et al., 2010; Frossard et al., 2011).

Surface measurements of aerosols are not representative of the troposphere, particularly in the Arctic because of strong stratification (Hansen and Rosen, 1984; Hansen and Novakov, 1989; Klonecki et al., 2003). The vertical distribution of aerosols has important implications for radiative forcing (Koch et al., 2009a). Two coordinated aircraft campaigns with carbonaceous aerosol measurements were conducted in April 2008 out of Fairbanks, Alaska: the NASA Arctic Research of the Composition of the Troposphere from Aircraft and Satellites (ARCTAS) (Jacob et al., 2010) and the NOAA Aerosol, Radiation and Cloud Processes affecting Arctic Climate (ARCPAC) (Brock et al., 2011). These two campaigns were part of the international program Polar Study using Aircraft, Remote Sensing, Surface Measurements and Models, of Climate, Chemistry, Aerosols and Transport (POLARCAT) (http://www.polarcat.no). They provided extensive vertical profiling of trace gases and speciated aerosols through the depth of the Arctic troposphere. They showed in particular large enhancements of carbonaceous aerosols in the mid-troposphere due to open fires in Russia and Kazakhstan (Warneke et al., 2009; Spackman et al., 2010; Warneke et al., 2010; Kondo et al., 2011; Matsui et al., 2011; McNaughton et al., 2011). More recent airborne measurements of BC in the Arctic were made in April 2009 during the PAM-ARCMIP campaign (Stone et al., 2010).

A number of CTM studies have investigated the sources of $\mathrm{BC}$ in the Arctic, but there are large disagreements among models and discrepancies with observations (Shindell et al., 2008; Koch et al., 2009b; Tilmes et al., 2011). Emissions in East Asia have grown rapidly in the past two decades and some work has pointed out an impact on winter-spring Arctic $\mathrm{BC}$ concentrations, especially in the free troposphere (Koch and Hansen, 2005; Shindell et al., 2008; Tilmes et al., 2011). However, Stohl (2006) found little wintertime Asian influence over the Arctic either at the surface or in the free troposphere. Liu et al. (2011) pointed out that simulation of transport of $\mathrm{BC}$ to the Arctic is highly sensitive to the model representation of wet and dry deposition.

Attempts to model OA over the Arctic have been more limited. Open fires would be expected to be a dominant source on an annual average basis (Koch et al., 2007). There is a general tendency for models to underestimate observed OA concentrations in the remote atmosphere (Heald et al., 2005, 2011), and this has been attributed to poor representation of secondary organic aerosol (SOA) formation (Volkamer et al., 2006; Hodzic et al., 2010; Heald et al., 2011).

We show here that the ensemble of ARCTAS and surface observations provide important constraints on the sources of $\mathrm{BC}$ and $\mathrm{OA}$ to the Arctic in winter-spring, and that the GEOS-Chem model with improved representation of wet deposition can successfully simulate these observations. Our work builds on previous studies that applied GEOS-Chem to simulate observations of other species over the Arctic during ARCTAS/ARCPAC including CO (Fisher et al., 2010), sulfate-ammonium aerosols (Fisher et al., 2011), $\mathrm{HO}_{\mathrm{x}}$ radicals (Mao et al., 2010), and mercury (Holmes et al., 2010). Fires were a dominant source of OA during ARCTAS/ARCPAC, but we show that anthropogenic (fossil fuel and biofuel) sources were more important for BC, particularly near the surface. Anthropogenic BC was mainly of Asian origin in the free troposphere but had comparable contributions from Asia, Europe, North America and Russia near the surface. Our results suggest that Russian anthropogenic sources are a major source of Arctic BC in winter, and that $\mathrm{BC}$ concentrations in Arctic air and snow are highest in the Eurasian sector in both winter and spring.

\section{Model description}

We use the GEOS-Chem CTM version 8-01-04 (http:// geos-chem.org) driven by assimilated meteorological data from the Goddard Earth Observing System (GEOS-5) of the NASA Global Modeling and Assimilation Office (GMAO). The GEOS-5 data have 6-hour temporal resolution (3-h for surface quantities and mixing depths), 47 vertical layers, and $0.5^{\circ} \times 0.667^{\circ}$ horizontal resolution. We degrade the horizontal resolution to $2^{\circ} \times 2.5^{\circ}$ for input to GEOS-Chem. We 
initialize the model with a one-month spin-up followed by simulation of Jan-May 2008.

The simulation of carbonaceous aerosols in GEOS-Chem is as described by Park et al. (2006) and Fu et al. (2009), with modifications of wet deposition and emission inventories described below. $\mathrm{BC}$ and primary $\mathrm{OA}$ (POA) are emitted by combustion. SOA is produced in the atmosphere by reversible condensation of oxidation products of biogenic and aromatic volatile organic compounds (Chung and Seinfeld, 2002; Henze and Seinfeld, 2006; Henze et al., 2008), as well as by irreversible condensation of glyoxal and methylglyoxal (Fu et al., 2008, 2009). We find that SOA formed by either of these pathways is negligible in the winter-spring Arctic and we do not discuss it further here. The simulations of BC and POA in GEOS-Chem are linear (concentrations are proportional to sources) and we isolate the contributions from different sources by tagging them in the model.

Dry deposition in GEOS-Chem follows a standard resistance-in-series scheme (Wesely, 1989) as implemented by Wang et al. (1998), with deposition velocities calculated locally using GEOS-5 data for surface values of momentum and sensible heat fluxes, temperature, and solar radiation. The global annual mean dry deposition velocity is $0.1 \mathrm{~cm} \mathrm{~s}^{-1}$ for BC and OA, typical of current models (Reddy and Boucher, 2004; Huang et al., 2010). Over snow/ice the Wesely (1989) parameterization yields a mean dry deposition velocity of $0.08 \mathrm{~cm} \mathrm{~s}^{-1}$. Fisher et al. (2011) previously found that this leads to GEOS-Chem underestimate of sulfate at Arctic surface sites, and we find the same for BC. Following Fisher et al. (2011), we impose a constant aerosol dry deposition velocity of $0.03 \mathrm{~cm} \mathrm{~s}^{-1}$ over snow and ice based on eddy-covariance flux measurements in the Arctic by Nilsson and Rannik (2001) and Held et al. (2011). With this assumption and as discussed later, we find in the model that dry deposition contributes only $15 \%$ of total $\mathrm{BC}$ deposition to the Arctc in winter and $9 \%$ in spring. Similar BC dry deposition velocities $\left(0.01-0.07 \mathrm{~cm} \mathrm{~s}^{-1}\right)$ over snow/ice were adopted in Liu et al. (2011) to improve their BC simulation over the Arctic in the AM-3 global model.

\subsection{Wet deposition}

Proper representation of scavenging by cold (ice) clouds and snow is important for simulation of aerosols in the Arctic. The standard scheme for aerosol scavenging in GEOS-Chem described by Liu et al. (2001) includes scavenging in convective updrafts, as well as in-cloud and below-cloud scavenging from convective and large-scale precipitation. However, it does not distinguish between rain and snow. Here we introduce such a distinction as well as other improvements to the scavenging scheme.

In the standard GEOS-Chem model, below-cloud scavenging (washout) of aerosol mass is calculated using a washout rate constant $k=a P$, where $P$ is the precipitation rate $\left(\mathrm{mm} \mathrm{h}^{-1}\right)$ and $a=0.1 \mathrm{~mm}^{-1}$ is a washout coeffi- cient obtained by integrating scavenging efficiencies from impaction, interception, and diffusion over typical raindrop and aerosol size distributions (Dana and Hales, 1976). This overestimates integrated scavenging during a precipitation event because it does not account for the preferential removal of coarse particles, shifting the aerosol size distribution toward the more scavenging-resistant accumulation mode (Feng, 2007; Croft et al., 2009; Feng, 2009). Here we use a parameterization $k=a P^{b}$ constructed by Feng (2007, 2009) for individual aerosol modes (nucleation, accumulation, and coarse) and for snow as well as rain. We adopt their accumulation-mode scavenging coefficients for all aerosols except dust and sea salt, for which we adopt their coarsemode coefficients. The corresponding values for rain $(T \geq$ $268 \mathrm{~K})$ are $a=1.1 \times 10^{-3}$ and $b=0.61$ for accumulationmode aerosols, and $a=0.92$ and $b=0.79$ for coarse-mode aerosols; for snow $(T<268 \mathrm{~K})$, they are $a=2.8 \times 10^{-2}$ and $b=0.96$ for accumulation-mode aerosols, and $a=1.57$ and $b=0.96$ for coarse-mode aerosols. Here $P$ is in units of $\mathrm{mm} \mathrm{h}^{-1}, k$ is in unit of $\mathrm{h}^{-1}$, and the units of $a$ depend on the value of $b$. Scavenging of accumulation-mode aerosols by snow is 5-25 times more efficient than by rain for $P$ in the range $0.01-1 \mathrm{~mm} \mathrm{~h}^{-1}$ because of the larger cross sectional area of snow crystals vs. rain drops (Murakami et al., 1983). The difference increases as $P$ increases.

In-cloud scavenging (rainout) efficiently removes aerosols serving as cloud condensation nuclei $(\mathrm{CCN})$ or ice nuclei (IN). In the case of warm (liquid) and mixed-phase clouds ( $T \geq 258 \mathrm{~K}$ ), we assume $100 \%$ incorporation of hydrophilic aerosols in the cloud droplets followed by efficient scavenging when liquid water is converted to precipitation by coalescence or riming. We assume that $80 \%$ of $\mathrm{BC}$ and $50 \%$ of POA are emitted as hydrophobic (Cooke et al., 1999; Park et al., 2003), and convert them to hydrophilic in the atmosphere with an e-folding time of 1 day which yields a good simulation of BC export efficiency in continental outflow (Park et al., 2005). In the case of cold clouds ( $T<258 \mathrm{~K})$, we assume that only dust and hydrophobic BC can serve as IN and hence be removed by scavenging (Chen et al., 1998; Andreae and Rosenfeld, 2008). Cozic et al. (2007) find that the BC fraction scavenged into cloud droplets decreases with decreasing temperature, from $60 \%$ at $0{ }^{\circ} \mathrm{C}$ to $10 \%$ at $<-20^{\circ} \mathrm{C}$. However, it must be recognized that the scavenging of $\mathrm{BC}$ by cold clouds is highly uncertain (Karcher et al., 2007; Baumgardner et al., 2008; Cozic et al., 2008; Targino et al., 2009; Stith et al., 2011).

Precipitation is a subgrid process on the horizontal scale of GEOS-Chem. A critical variable in the wet deposition parameterization is the areal fraction $F_{k}$ of a grid box at vertical model layer $k$ that actually experiences precipitation. Liu et al. (2001) applied the formulation of Giorgi and Chameides (1986) for the areal fraction $F_{k}^{\prime}$ over which new precipitation is formed:

$F_{k}^{\prime}=\frac{Q_{k}}{L C_{1}}$ 

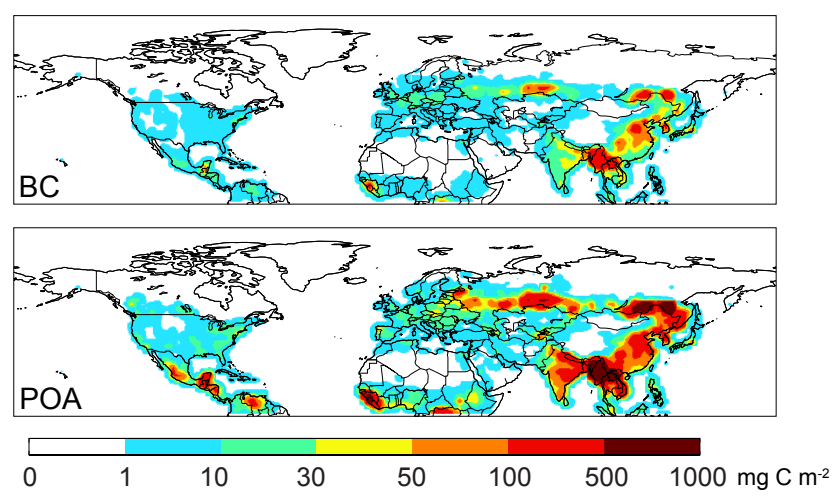

Fig. 1. GEOS-Chem emissions of black carbon (BC) and primary organic aerosol (POA) in April 2008. Annual regional totals are in Table 1.

where $Q_{k}$ is the grid-scale formation rate of new precipitation $\left(\mathrm{kg} \mathrm{m}^{-3} \mathrm{~s}^{-1}\right), L$ is the condensed water content of the precipitating cloud and is assumed to be constant ( $L=$ $1.0 \times 10^{-3} \mathrm{~kg} \mathrm{~m}^{-3}$ ) (DelGenio et al., 1996), and $C_{1}$ is the rate constant for conversion of cloud water to precipitation $\left(C_{1}=C_{1 \mathrm{~min}}+Q_{k} / L\right.$ with $\left.C_{1 \mathrm{~min}}=1.0 \times 10^{-4} \mathrm{~s}^{-1}\right)$. The algorithm is initiated for each grid square at the top of the tropospheric column and proceeds downward, computing the actual precipitating fraction $F_{k}$ in layer $k$ (index decreasing downward $)$ as $F_{k}=\max \left(F_{k}^{\prime}, F_{k+1}\right)$ to account for precipitation formation overhead. In previous versions of GEOSChem, $Q_{k}>0$ caused rainout to be applied to the whole precipitation area fraction $F_{k}$ and washout was only applied when $F_{k}>0$ and $Q_{k} \leq 0$ (negative $Q_{k}$ indicating net evaporation). This caused an overestimation of in-cloud scavenging and underestimation of below-cloud scavenging, as $F_{k+1}>F^{\prime}{ }_{k}$ should be an indication of washout taking place over the fractional area $F_{k+1}-F^{\prime}{ }_{k}$ of layer $k$. In our present simulation, we apply rainout in layer $k$ to the precipitating fraction $F^{\prime}{ }_{k}$ and washout to the additional fractional area $F_{\text {diff }}=\max \left(0, F_{k+1}-F^{\prime}{ }_{k}\right)$. The correction slows aerosol scavenging as washout is generally less efficient than rainout.

Liu et al. (2011) found in the AM-3 model a factor of 100 increase in winter-spring Arctic BC, and better agreement with observations from surface sites and from ARCTAS, by using a photochemically-varying timescale for BC hydrophobic-to-hydrophilic aging (up to 1-2 weeks in winter) and reducing total deposition efficiencies relative to their original model. They found in their model that $30-50 \%$ of Arctic BC remained hydrophobic in winter. However, the significant coating of $\mathrm{BC}$ particles indicated by aircraft observations of shell/core ratios (Kondo et al., 2011) and light absorption (McNaughton et al., 2011) in ARCTAS suggests that $\mathrm{BC}$ in the Arctic is mainly hydrophilic. In addition, TRACE-P aircraft observations in Asian outflow in March-
April provide good constraints that the $\mathrm{BC}$ aging time scale is no more than 2 days (Park et al., 2005).

Model transport of aerosol from northern mid-latitudes to the Arctic is highly sensitive to the representation of wet deposition (Liu et al., 2011). There are many associated uncertainties including model precipitation and its vertical distribution, the subgrid scale of precipitation coupled to transport, and the scavenging efficiencies from washout and rainout. The tropospheric lifetime of $\mathrm{BC}$ against deposition in our simulation is 5.9 days, not significantly different from the standard GEOS-Chem model (5-6 days), and within the range of 5-11 days from current models (Koch et al., 2009b). Wet deposition accounts globally for $77 \%$ of annual BC deposition, consistent with the AeroCom multimodel assessment $(78.6 \pm 17 \%)$ (Textor et al., 2006). The tropospheric lifetime of ${ }^{210} \mathrm{~Pb}$ aerosol in the model is 10.4 days (Amos et al., 2011), consistent with observational constraints (Liu et al., 2001). With regard to the Arctic, our successful simulation of observations combined with the relatively good constraints on emissions (see discussion below) gives some confidence to our scavenging parameterization. Fisher et al. (2011) previously showed that it allows a successful simulation of sulfate-ammonium aerosol in ARCTAS.

\subsection{Emissions of $\mathrm{BC}$ and $\mathrm{OA}$}

Figure 1 shows the hemispheric emissions of $\mathrm{BC}$ and POA (primary organic aerosol) in April 2008 in the model. Table 1 gives regional and global annual totals for 2008. Anthropogenic emissions (fossil fuel and biofuel combustion) are from Bond et al. (2007) for 2000, but with doubled emissions in Russia and Asia for both BC and POA to match BC surface observations in China and in the Arctic as discussed below. This doubling is consistent with the strong recovery of the Russian economy since 2000 (IEA, 2010) and with the general increase in Chinese emissions over the past decade (Zhang et al., 2008a; Lu et al., 2010).

Open fires (not necessarily nature) are a major source of carbonaceous aerosols. April 2008 saw exceptionally high forest and agricultural fire activity in Russia and Kazahkstan (hereafter referred to collectively as "Russia") (Warneke et al., 2009; Fisher et al., 2010) as well as typical seasonal fire activity in Southeast Asia (including India and southern China). We specify open fire emissions with the Fire Locating and Monitoring of Burning Emissions (FLAMBE) inventory (Reid et al., 2009), which has $1^{\circ} \times 1^{\circ}$ spatial resolution and hourly temporal resolution based on MODIS and GOES satellite fire counts. The FLAMBE inventory provides fine particle $\left(\mathrm{PM}_{2.5}\right)$ emissions based on total estimated fuel combustion, carbon fraction in the fuel, and $\mathrm{PM}_{2.5}$ emission factors (Reid et al., 2005, 2009). We partition $\mathrm{PM}_{2.5}$ emissions into $\mathrm{BC}$ and $\mathrm{OA}$ using $\mathrm{BC} / \mathrm{OA}$ emission ratios from Andreae and Merlet (2001) for different vegetation types. Fisher et al. (2010) previously used FLAMBE to simulate ARCTAS/ARCPAC CO observations with GEOS-Chem and 
Table 1. Global GEOS-Chem emissions of carbonaceous aerosols in $2008^{\mathrm{a}}$.

\begin{tabular}{|c|c|c|}
\hline Source & $\begin{array}{r}\text { Black Carbon } \\
\qquad\left(\mathrm{TgCa}^{-1}\right)\end{array}$ & $\begin{array}{r}\text { Organic Aerosol } \\
\qquad\left(\mathrm{Tg} \mathrm{Ca}^{-1}\right)\end{array}$ \\
\hline Anthropogenic ${ }^{b}$ & 7.0 & 14 \\
\hline North America $\left(172.5-17.5^{\circ} \mathrm{W}, 24-88^{\circ} \mathrm{N}\right)$ & 0.41 & 0.56 \\
\hline $\begin{array}{l}\text { Europe }\left(17.5^{\circ} \mathrm{W}-30^{\circ} \mathrm{E}, 50-88^{\circ} \mathrm{N} \& 17.5^{\circ} \mathrm{W}-\right. \\
\left.60^{\circ} \mathrm{E}, 33-50^{\circ} \mathrm{N}\right)\end{array}$ & 0.63 & 1.1 \\
\hline Russia $\left(30-172.5^{\circ} \mathrm{E}, 50-88^{\circ} \mathrm{N}\right)$ & 0.23 & 0.52 \\
\hline Asia $\left(60-152.5^{\circ} \mathrm{E}, 0-50^{\circ} \mathrm{N}\right)$ & 4.7 & 9.8 \\
\hline Rest of world & 1.0 & 2.6 \\
\hline Open Fires ${ }^{\mathrm{c}}$ & 11 & 84 \\
\hline North America $\left(172.5-17.5^{\circ} \mathrm{W}, 24-88^{\circ} \mathrm{N}\right)$ & 0.20 & 2.7 \\
\hline Europe $\left(17.5^{\circ} \mathrm{W}-30^{\circ} \mathrm{E}, 33-88^{\circ} \mathrm{N}\right)$ & 0.082 & 0.63 \\
\hline Russia $\left(30-152.5^{\circ} \mathrm{E}, 33-60^{\circ} \mathrm{N}\right)$ & 0.60 & 4.5 \\
\hline South Asia $\left(60-152.5^{\circ} \mathrm{E}, 0-33^{\circ} \mathrm{N}\right)$ & 0.77 & 6.1 \\
\hline Rest of world & 9.5 & 70 \\
\hline Total & 18 & 98 \\
\hline
\end{tabular}

a Values are annual means. Different region definitions are used for anthropogenic and open fire sources.

b Including fossil fuel and biofuel combustion. Values are from Bond et al. (2007) but with doubling of Russian and Asian emissions (see text).

${ }^{c}$ From the FLAMBE inventory of Reid et al. (2009) but with major modifications for Russian and Southeast Asian sources as described in the text.

found that Russian and Southeast Asian emissions needed to be reduced to $53 \%$ and $45 \%$, respectively, of the original FLAMBE values. We apply here the same reductions to $\mathrm{BC}$ and $\mathrm{OA}$ emissions and further correct the emissions to fit the ARCTAS data. Open fires in Russia were the dominant source of OA in ARCTAS (Warneke et al., 2009, 2010), and we find from tagged source attribution that OA emissions from Russian fires must be reduced by an additional $36 \%$ to match the ARCTAS observations. Our resulting OA emission factor from the Russian fires is 6.8 grams carbon per kilogram dry mass burned, consistent with the 3.3-9.7 range reported in the literature for agricultural and extratropical forest fires (Andreae and Merlet, 2001; Akagi et al., 2011).

From there we use observations of the BC/OA concentration ratio in fire plumes to constrain the $\mathrm{BC}$ emission factor. Warneke et al. (2009) reported BC/OA ratios of 0.14 (agricultural fires) and 0.15 (forest fires) on a carbon basis for Russian fire plumes sampled in ARCPAC, and we find a similar observed ratio of $0.12 \pm 0.03$ for fire plumes sampled in ARCTAS (Fig. 2). The model as specified above, with a BC/OA emission ratio of 0.13 , reproduces these observed values in the fire plumes and we have no need to adjust them further. The resulting $\mathrm{BC}$ emission factor from the Russian fires is $0.87 \mathrm{~g} \mathrm{~kg}^{-1}$ (gram carbon per kilogram dry mass burned), at the high end of the 0.37-0.82 range reported in the literature for agricultural and extratropical forest fires (Andreae and Merlet, 2001; Akagi et al., 2011).

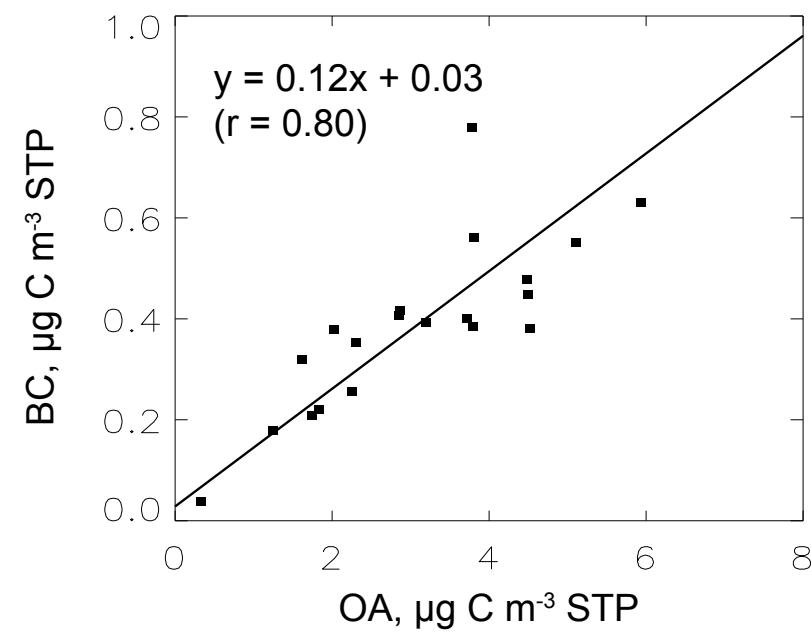

Fig. 2. Scatterplot of $B C$ vs. $O A$ concentrations in fire plumes diagnosed by $\left[\mathrm{CH}_{3} \mathrm{CN}\right]>200 \mathrm{ppt}$ for the ensemble of ARCTAS DC-8 flights (1-19 April 2008). STP refers to standard conditions of temperature and pressure $(273 \mathrm{~K}, 1 \mathrm{~atm})$ so that $\mu \mathrm{g} \mathrm{C} \mathrm{m}^{-3} \mathrm{STP}$ is a mixing ratio unit. The reduced-major-axis (RMA) regression is shown by the solid line and the corresponding equation is given in the inset.

Figure 3 compares annual mean surface air concentrations of $\mathrm{BC}$ in the model in 2008 with observations from networks in the US (2008), China (2006), and Europe (2002-2003). Our objective is to diagnose any large model 

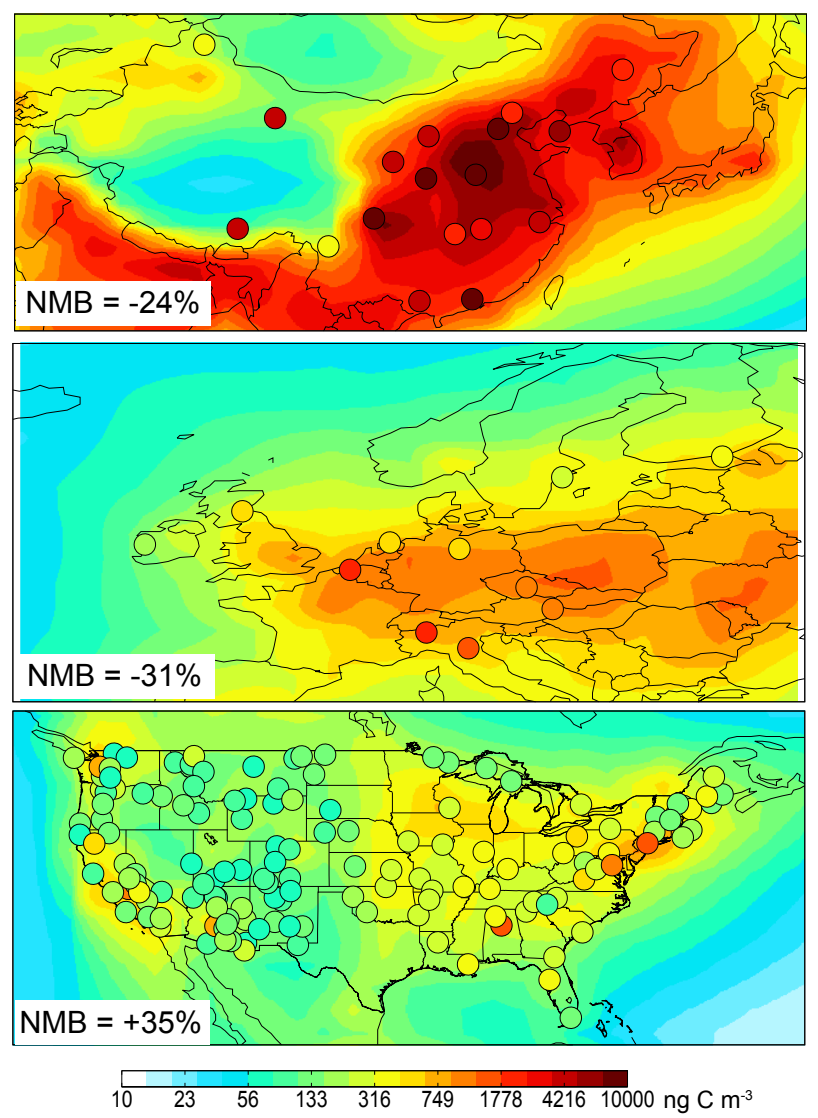

Fig. 3. Annual mean surface air concentrations of $B C$ aerosol in China, Europe, and the US. Model results for 2008 (solid contours) are compared to observations (circles). Observations are from Zhang et al. (2008a) in China for 2006, from the EMEP network in Europe for 2002-2003 (http://tarantula.nilu.no/projects/ ccc/emepdata.html), and from the IMPROVE network in the US for 2008 (http://vista.cira.colostate.edu/improve/Data-/IMPROVE/ AsciiData.aspx). Normalized mean bias (NMB) statistics for each region are shown inset.

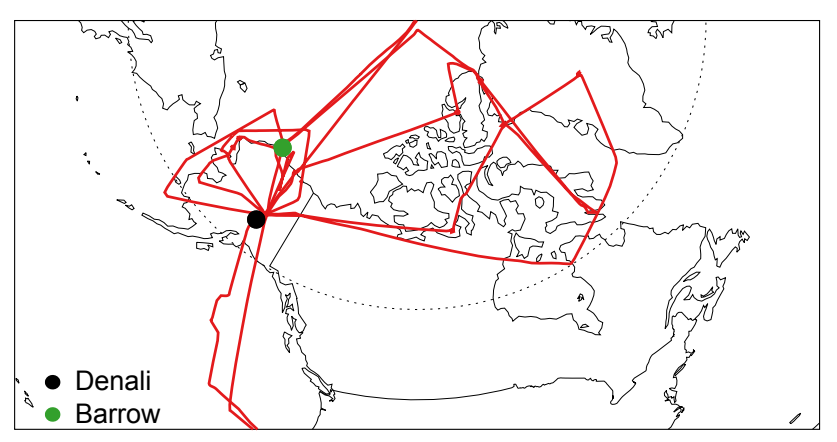

Fig. 4. DC-8 flight tracks during the April 2008 ARCTAS campaign (red lines). Long-term monitoring sites for $\mathrm{BC}$ at Barrow and Denali are also indicated. bias in these three major source regions relevant to the Arctic. For the US we use 2008 data from the rural IMPROVE network (http://vista.cira.colostate.edu/improve/ Data/IMPROVE/AsciiData.-aspx). For China and Europe we do not have network observations for 2008 and therefore use data for other years with the assumption that interannual variability is small: Zhang et al. (2008b) for ru$\mathrm{ral} /$ regional sites in China in 2006, and the BC/OC campaign in Europe in 2002-2003 (http://tarantula.nilu.no/projects/ $\mathrm{ccc} /$-emepdata.html). We diagnose for each region the normalized mean bias:

$\mathrm{NMB}=100 \% \times \sum_{i}\left(M_{i}-O_{i}\right) / \sum_{i} O_{i}$

where the sum is over the ensemble of sites $i$, and $M_{i}$ and $O_{i}$ are the modeled and observed values, respectively.

The data in Fig. 3 show normalized mean biases of $-24 \%$ for China, $-31 \%$ for Europe, and $+35 \%$ for the US. Without doubling the inventory from Bond et al. (2007) the bias for China would be much larger $(\mathrm{NMB}=-61 \%)$. Underestimation in Europe is mainly due to three sites in northern Italy and Belgium. Without these three sites the NMB would decrease to $-0.7 \%$. The overestimation of BC in the US can be explained by a $40 \%$ decrease in observed concentrations between 2000 (year of the Bond et al. (2007) inventory) and 2008, as shown by Leibensperger et al. (2011).

\section{Sources of $\mathrm{BC}$ and $\mathrm{OA}$ in the Arctic}

\subsection{Constraints from aircraft data}

Figure 4 shows the DC-8 flight tracks in ARCTAS. BC was measured with an SP2 (Single Particle Soot Photometer) instrument in the size range $0.08-0.860 \mu \mathrm{m}$ (Kondo et al., 2011). OA and other aerosol concentrations were measured by an Aerosol Mass Spectrometer (AMS) in the size range 0.045-1 $\mu \mathrm{m}$ (Jimenez et al., 2003). We assume that these measurements account for the bulk of $\mathrm{BC}$ and OA mass. The AMS measures OA in units of $\mu \mathrm{g} \mathrm{m}^{-3}$ and we convert this to $\mu \mathrm{g} \mathrm{C} \mathrm{m}^{-3}$ with a scaling factor of 2.1 typical of nonurban aerosols (Turpin and Lim, 2001; Aiken et al., 2008). The model is sampled along the flight tracks at the same time and location as the observations, and the aircraft data are averaged over the GEOS-Chem grid. Observations outside the Arctic (south of $60^{\circ} \mathrm{N}$ ), in the stratosphere $\left(\left[\mathrm{O}_{3}\right] /[\mathrm{CO}]\right.$ $\left.>1.25 \mathrm{~mol} \mathrm{~mol}^{-1}\right)$, and in fire plumes $\left(\left[\mathrm{CH}_{3} \mathrm{CN}\right]>200 \mathrm{ppt}\right)$ are excluded. We previously used the information from fire plumes to constrain the BC emission factor (Sect. 2).

$\mathrm{BC}$ and $\mathrm{OA}$ were measured from the ARCPAC aircraft concurrently with ARCTAS, but for fewer flights and a much smaller spatial domain in the Alaskan Arctic. Fisher et al. (2011) previously compared the GEOS-Chem sulfateammonium aerosol simulation to the ensemble of ARCTAS and ARCPAC observations, and found the ARCPAC data difficult to interpret because of the limited sampling and focus 


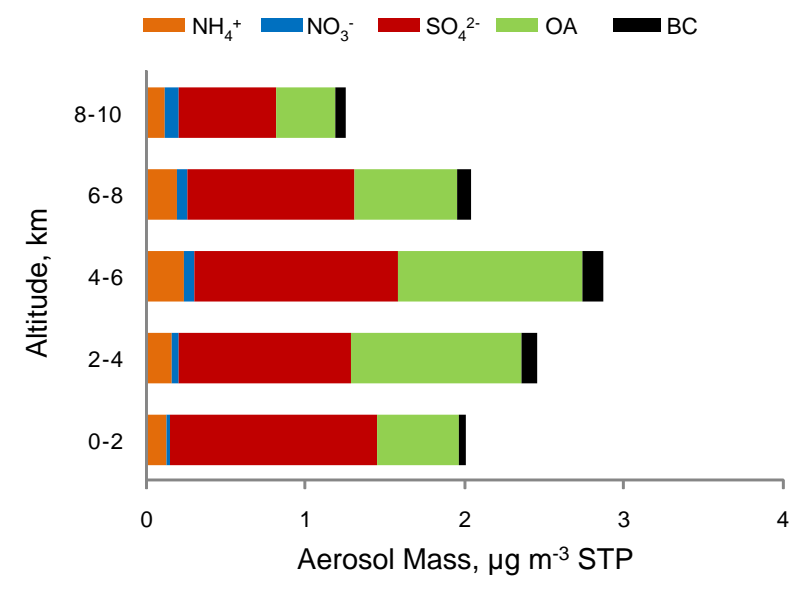

Fig. 5. Fine aerosol composition observed along the ARCTAS DC8 flight tracks (1-19 April 2008), averaged over 2-km altitude bins. The averaging excludes data collected south of $60^{\circ} \mathrm{N}$, in stratospheric air, and in biomass burning plumes (see text).

on fire plumes. We limit here our use of the ARCPAC data to the constraints that they provide on biomass burning emission factors (Warneke et al., 2009, 2010) and BC dry deposition (Spackman et al., 2010).

Figure 5 shows the overall fine aerosol composition measured by the ARCTAS DC-8 in 2-km altitude bins, providing context for the relative importance of BC and OA. Sea salt and dust are excluded as only bulk measurements were made in ARCTAS and we expect their coarse-mode fractions to be dominant. OA and sulfate are the dominant components of the fine aerosol. Sulfate is dominant in surface air but OA becomes comparable in the free troposphere, because sulfate shows little variation with altitude while OA is strongly peaked at $2-6 \mathrm{~km}$.

Figure 6 shows scatterplots of simulated vs. observed BC and OA concentrations during ARCTAS, and Fig. 7 shows mean vertical profiles. The model has some success in reproducing the variability of the individual observations, with a correlation coefficient $r=0.65$ for $\mathrm{BC}$ and 0.62 for OA. There are some large underestimates in the mid-troposphere associated with elevated $\mathrm{CH}_{3} \mathrm{CN}$, a tracer of biomass burning, but these may reflect the inability of the model to resolve fine plumes not screened by the $\left[\mathrm{CH}_{3} \mathrm{CN}\right]<200 \mathrm{ppt}$ filter. Concentrations of $\mathrm{BC}$ average $53 \pm 109 \mathrm{ng} \mathrm{C} \mathrm{m}^{-3}$ in the observations and $63 \pm 65 \mathrm{ng} \mathrm{C}^{-3}$ in the model. Concentrations of $\mathrm{OA}$ average $0.40 \pm 0.56 \mu \mathrm{g} \mathrm{C} \mathrm{m}^{-3}$ in the observations and $0.35 \pm 0.37 \mu \mathrm{g} \mathrm{C} \mathrm{m}^{-3}$ in the model.

The model successfully reproduces the mean vertical distributions of $\mathrm{BC}$ and $\mathrm{OA}$, with peaks in the mid-troposphere. Also shown in Fig. 7 is the model source attribution using tagged tracers as described in Sect. 2. Since the model relationship between sources and concentrations is linear, the source contributions are additive and the sensitivity to source magnitudes can be readily inferred from the data shown here.
We see that the mid-troposphere peaks are due to Russian fires, and in the case of BC also to Asian anthropogenic influence. Open fires contribute $46 \%$ of BC and $84 \%$ of OA at $2-$ $6 \mathrm{~km}$ altitude in the model. The mid-tropospheric maximum reflects the lifting of Russian fire and Asian pollution effluents by warm conveyor belts (WCBs) originating from the Pacific Rim of the Asian continent (Liu et al., 2003; Stohl, 2006; Fisher et al., 2010). The strong influence of open fires at $2-6 \mathrm{~km}$ is consistent with the observed strong correlations of $\mathrm{BC}$ vs. $\mathrm{CH}_{3} \mathrm{CN}(r=0.74)$ and $\mathrm{OA}$ vs. $\mathrm{CH}_{3} \mathrm{CN}(r=0.81)$ and has been reported in previous ARCTAS/ARCPAC analyses (Warneke et al., 2009; Spackman et al., 2010; Warneke et al., 2010; Kondo et al., 2011; Matsui et al., 2011).

We find that open fires are the dominant source of OA at all altitudes in the model, but anthropogenic sources are more important for BC and dominate near the surface (Fig. 7). We evaluate this source attribution by using observed and simulated correlations with sulfate, an aerosol tracer of anthropogenic influence. Simulated GEOS-Chem sulfate is from Fisher et al. (2011). Figure 8 shows observed and simulated scatterplots of $\mathrm{BC}$ and $\mathrm{OA}$ vs. sulfate, indicating good agreement in the correlation coefficients and the slopes of the regression lines at 2-6 km (mid-troposphere) and 0-1 km (near-surface). There is significant correlation between OA and sulfate in the mid-troposphere, consistent with the wellknown mixing of pollution and fire influences in Asian outflow lifted by WCBs (Bey et al., 2001) and previously documented in ARCTAS and ARCPAC (Fisher et al., 2010; Brock et al., 2011). Figure 8 shows a population of points at altitude $>6 \mathrm{~km}$ with extremely high sulfate concentrations ( $>3 \mu \mathrm{g} \mathrm{m}^{-3} \mathrm{STP}$ ) and low BC and OA concentrations, corresponding to a plume transported from East Asia as indicated by back-trajectories. The strong enrichment of sulfate relative to carbonaceous aerosols in that plume is consistent with Asian pollution having experienced wet scavenging, as previously shown by van Donkelaar et al. (2008) and Dunlea et al. (2009) in observations from the INTEX-B aircraft campaign.

The contribution of open fire emissions in the model decreases from the mid-troposphere to near-surface air $(<1 \mathrm{~km})$, where it accounts for $20 \%$ of BC and $60 \%$ of $\mathrm{OA}$. The concentration ratios relative to sulfate are also much lower in near-surface air than in the mid-troposphere, both in the model and in observations (Fig. 8). This is consistent with Fisher et al. (2011), who found a major contribution to Arctic boundary layer sulfate from boundary layer transport of European and North American pollution, in contrast to the mid-troposphere where Asian pollution dominates. This boundary layer anthropogenic influence is far more important for $\mathrm{BC}$ than for OA because of the much higher BC/OA emission ratio from anthropogenic sources than from open fires (Table 1). Consequently, the observed ratio of BC vs. $\mathrm{OA}$ increases from 0.17 in the mid-troposphere to 0.26 near the surface (Fig. 9), and this is also well captured in the model. 


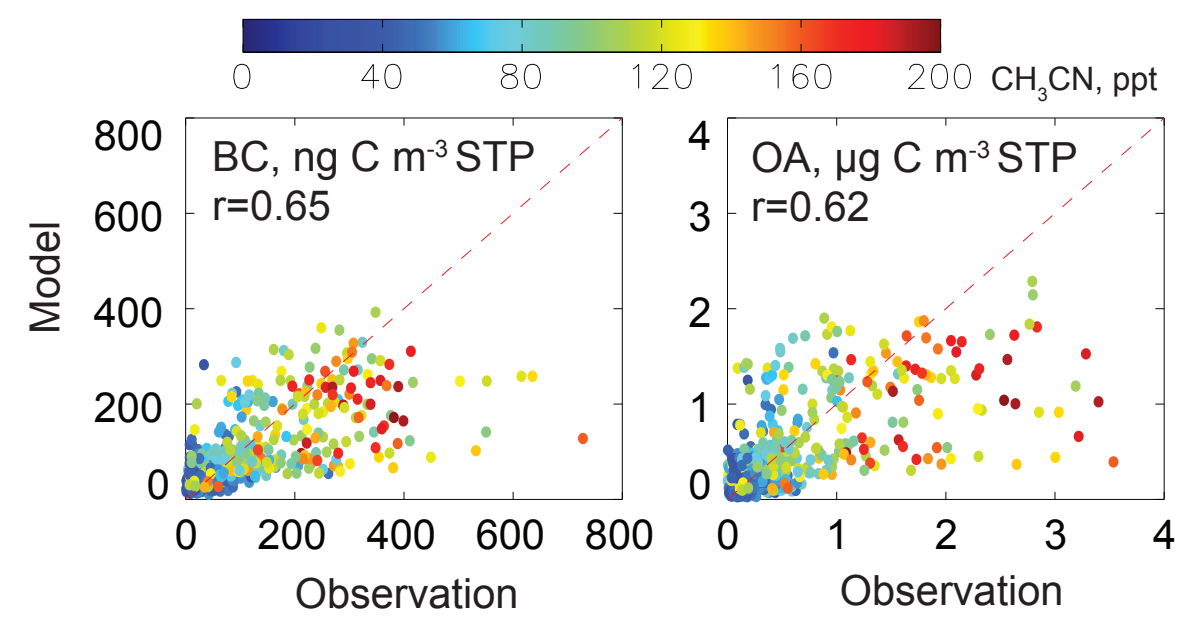

Fig. 6. Scatterplots of simulated vs. observed BC and OA concentrations along the DC-8 flight tracks during ARCTAS (1-19 April 2008). Colors indicate the corresponding concentrations of $\mathrm{CH}_{3} \mathrm{CN}$, a tracer of biomass burning. The 1:1 line is also shown.
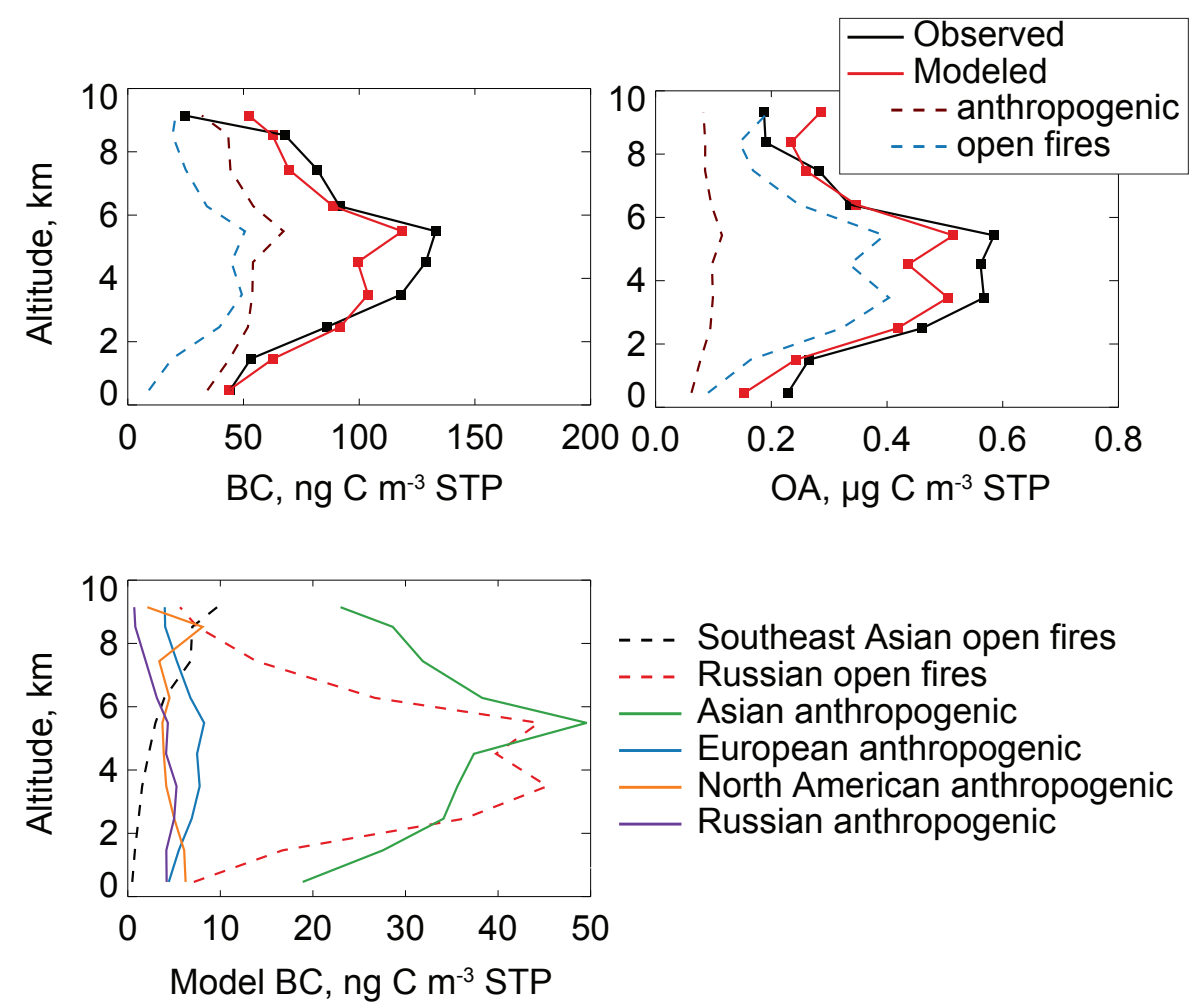

Fig. 7. Mean vertical profiles of BC and OA concentrations along the DC-8 flight tracks in ARCTAS (1-19 April 2008), averaged over 1-km altitude bins. The top panels compare observations to GEOS-Chem and separate the model contributions from anthropogenic and open fire sources. The bottom panel further separates model BC contributions by source regions. Anthropogenic sources include fossil fuel and biofuel combustion.

Our estimation of the open fire contribution to $\mathrm{BC}$ along the ARCTAS DC-8 flight tracks agrees with the value of 33$41 \%$ reported by McNaughton et al. (2011) using $\mathrm{CH}_{3} \mathrm{CN}$ and the $\mathrm{OA} /$ sulfate ratio to classify the data. Matsui et al. (2011) attributed most of the BC measured in ARCTAS to Russian fire emissions using $\mathrm{CH}_{3} \mathrm{CN}$ and dichloromethane $\left(\mathrm{CH}_{2} \mathrm{Cl}_{2}\right)$ to classify the data, but their analysis focused on plumes and ignored background air. 

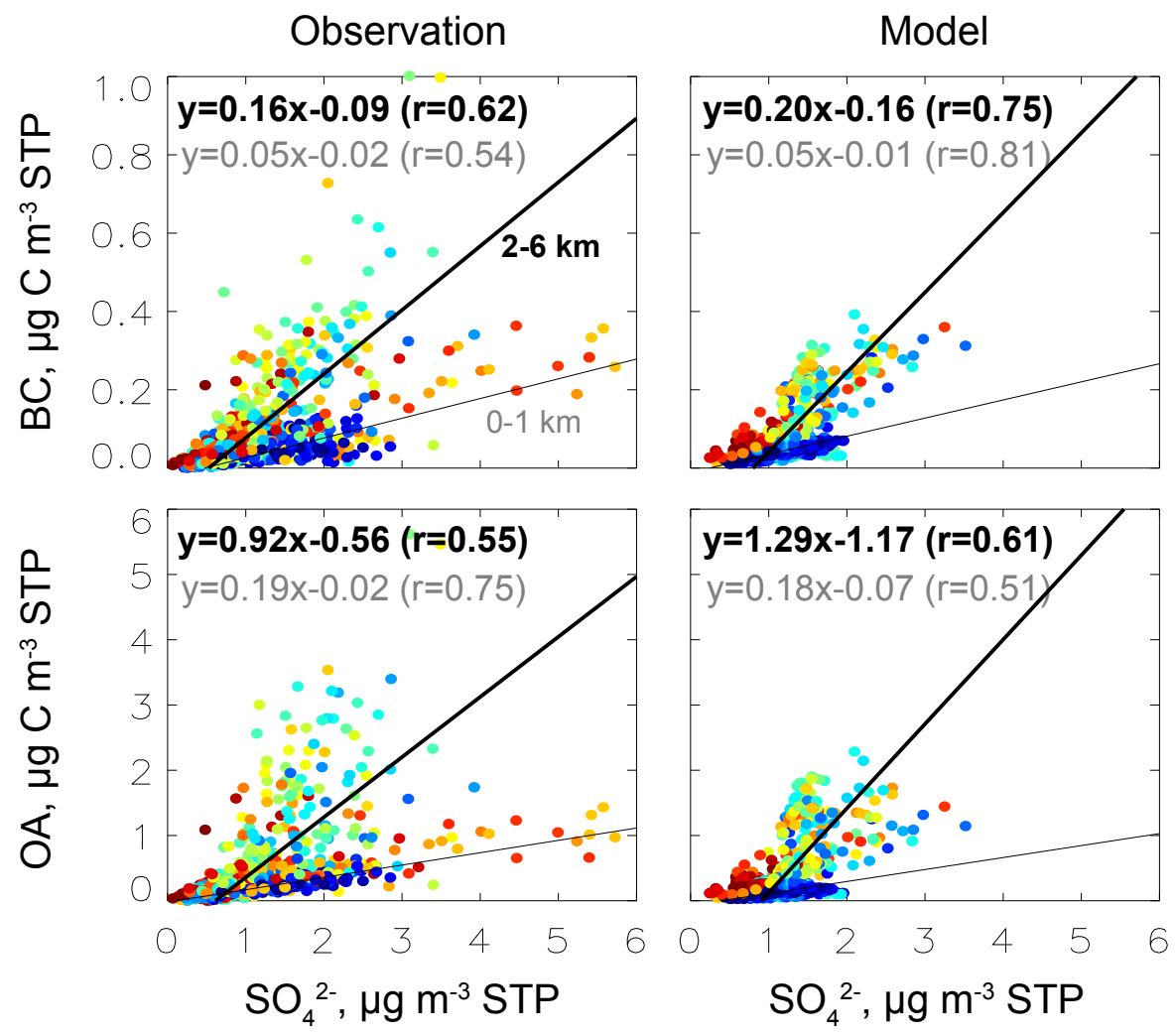

\section{$\begin{array}{llllllllll}0 & 1 & 2 & 3 & 4 & 5 & 6 & 7 & 8 & \text { Altitude, } \mathrm{km}\end{array}$}

Fig. 8. Scatterplots of $\mathrm{BC}$ and $\mathrm{OA}$ vs. sulfate $\left(\mathrm{SO}_{4}^{2-}\right)$ concentrations in ARCTAS. Observations from the DC- 8 aircraft (left panels) are compared to model values (right panels) sampled along the aircraft flight tracks as described in the text. Individual points are colored by altitude. Reduced-major-axis (RMA) regression statistics and linear fits are shown in thin black for near-surface data $(<1 \mathrm{~km})$ and in thick black for mid-tropospheric data $(2-6 \mathrm{~km})$.
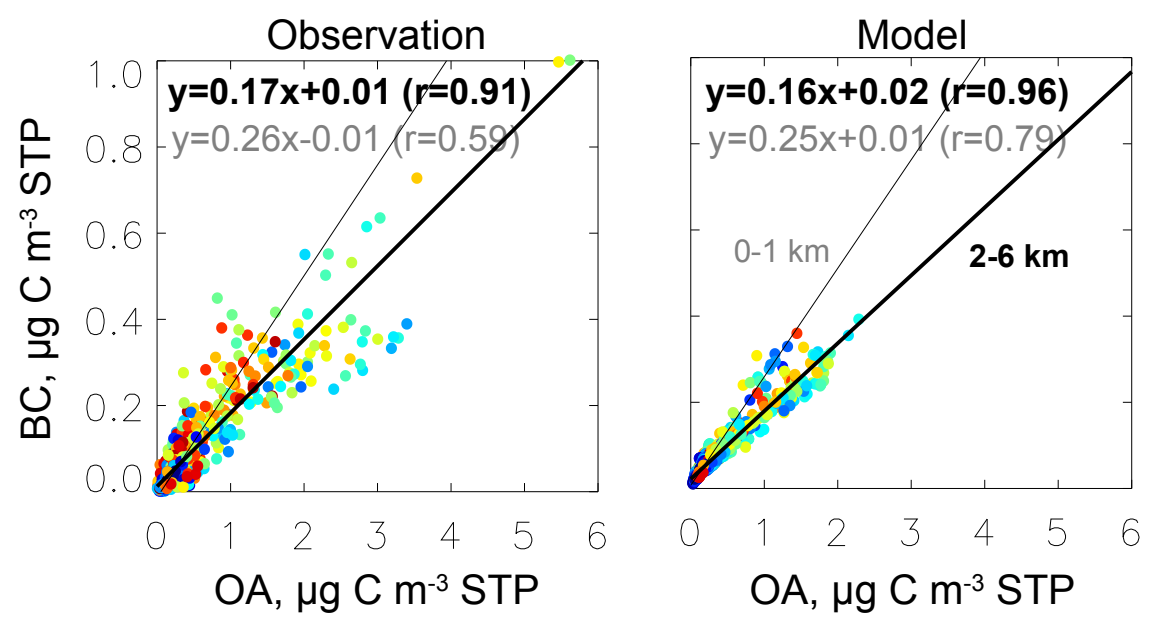

$\begin{array}{llllllllll}0 & 1 & 2 & 3 & 4 & 5 & 6 & 7 & 8 & \text { Altitude, } \mathrm{km}\end{array}$

Fig. 9. Same as Fig. 8 but for BC vs. OA concentrations in ARCTAS. 


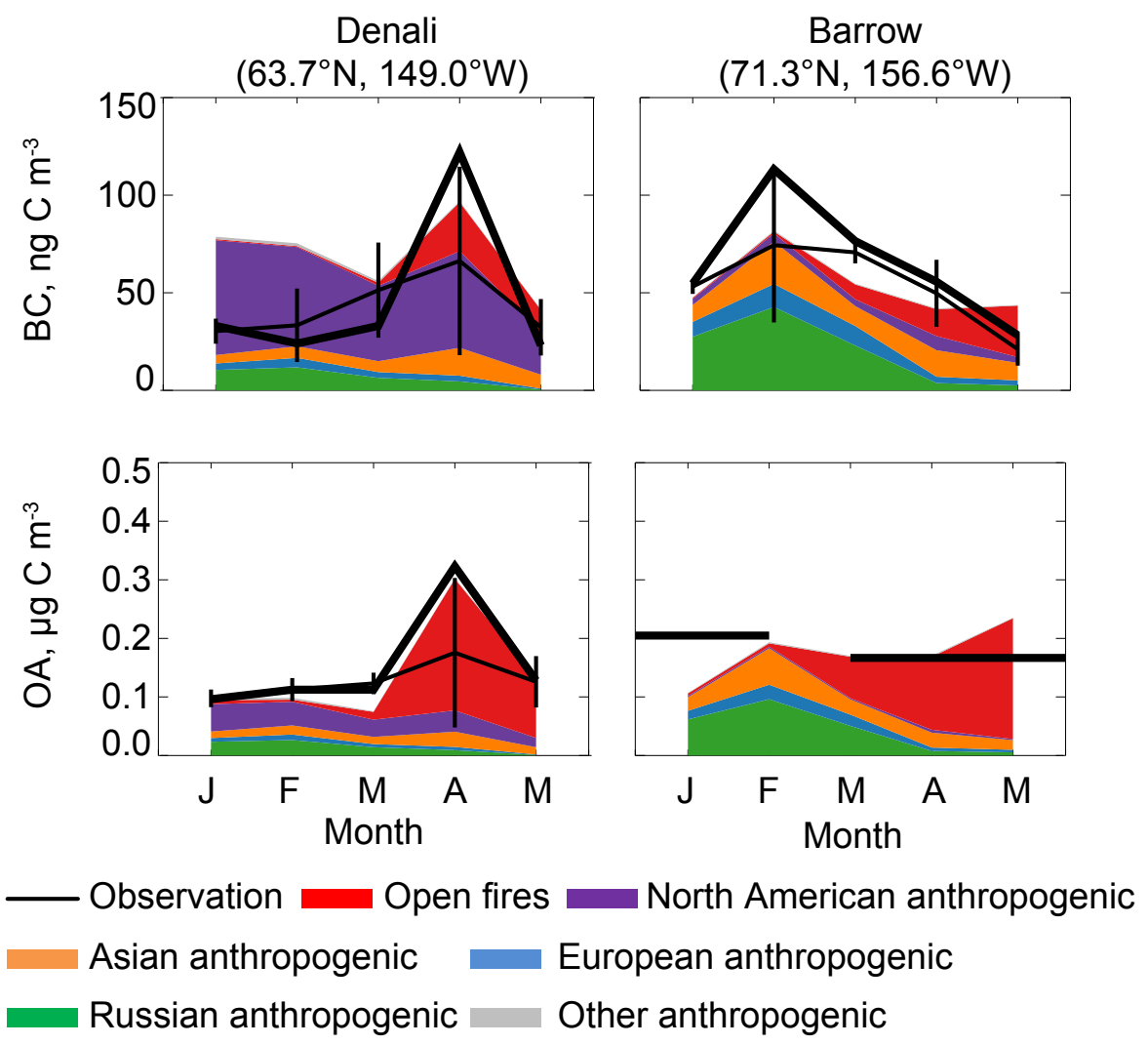

Fig. 10. Seasonal variation of $B C$ and $O A$ surface air concentrations at Denali and Barrow in Alaska. The thick black lines are monthly mean observations for 2008. The thin black lines are monthly mean observations for 2007-2009 with vertical bars representing interannual standard deviations. The thick line for OA at Barrow represents seasonal mean concentrations in Nov 2008-Feb 2009 and Mar-Jun 2008 from P. Shaw et al. (2010). Additive model contributions from different sources in the 2008 simulation are shown in color.

Broader examination of model results over the scale of the Arctic polar cap (north of $60^{\circ} \mathrm{N}$ ) in April 2008 indicates that open fire emissions contribute $50 \%$ of total BC in the Arctic tropospheric column and $81 \%$ of total OA. Fire influences are the strongest in the Eurasian Arctic (not sampled by the aircraft). Asian pollution dominates the source of anthropogenic $\mathrm{BC}$ in the Arctic tropospheric column, but less so in surface air. Our model Asian contribution to Arctic BC in spring is higher than previous studies (Koch and Hansen, 2005; Shindell et al., 2008; Tilmes et al., 2011). This reflects our higher Asian emission inventory, constrained by observations at Chinese sites as discussed in Sect. 2.

\subsection{Surface observations}

We now turn to surface observations in Jan-May 2008 to provide broader seasonal context. Figure 10 compares model results with monthly average surface concentrations observed in Alaska at Denali (low Arctic) and Barrow (high Arctic) in 2007-2009 (locations shown in Fig. 4). Model contributions from different sources are shown. Observations at Denali are from the IMPROVE network (http://vista.cira.colostate.
edu/-improve/Data/IMPROVE/AsciiData.aspx) using a thermal/optical reflectance method. Observations at Barrow are from the NOAA Global Monitoring Division (http://www. esrl.noaa.gov/gmd/aero/net/), reported as aerosol light absorption coefficients from a particle soot absorption photometer. We use a mass absorption efficiency of $9.5 \mathrm{~m}^{2} \mathrm{~g}^{-1}$ to convert the absorption coefficients to $\mathrm{BC}$ mass concentrations based on ARCTAS data (McNaughton et al., 2011). OA observations at Barrow are from P. Shaw et al. (2010), who reported seasonal mean concentrations for Mar 2008Mar 2009.

We find that the $\mathrm{BC}$ and $\mathrm{OA}$ observations at the surface sites in April 2008 are roughly consistent with the mean nearsurface ARCTAS data (Fig. 7), but are more affected by Russian fires. The fire influence at Denali is larger than that at Barrow. Observations in April 2008 were anomalously high relative to the 2007-2009 April mean (thin lines in Fig. 10), which reflects the anomalously large Russian fires (Fisher et al., 2010).

Observations of $\mathrm{BC}$ at Barrow show higher values in winter (Jan-Mar) than spring (Apr-May), even in 2008. In contrast, Denali shows higher values in spring even in the 
2007-2009 mean. The model fails to reproduce the seasonal variation at Denali, apparently because it overestimates local pollution influence from nearby Anchorage in winter. It is more successful at Barrow, although this is contingent on doubling of the Russian anthropogenic source from the Bond et al. (2007) inventory as described above. The winter maximum at Barrow is explained in the model by the Russian anthropogenic source, transported to the North American Arctic in the boundary layer around the Siberian High with little dilution and little precipitation. This Russian source influence declines sharply in spring due to vertical mixing and to the weakening of the Siberian High. Sharma et al. (2006) found similar source attribution for BC at Barrow using backtrajectory analysis, and Fisher et al. (2011) found similar results for sulfate at Barrow using GEOS-Chem.

Observed OA at Denali shows similar winter-spring seasonality as BC. Our model reproduces this seasonality without the spurious local influence from Anchorage seen for BC (the $\mathrm{OA} / \mathrm{BC}$ emission ratio from Anchorage in the Bond et al. (2007) inventory is 50\% lower than the anthropogenic mean). Observations of OA at Barrow show little seasonal variation between winter and spring, which is consistent with the model as the decline in the Russian anthropogenic source from winter to spring is compensated by the open fire influence. Both at Denali and at Barrow, we find that we can largely explain the wintertime OA on the basis of anthropogenic sources and the springtime OA on the basis of open fires. The source attribution in spring is consistent with the work of P. Shaw et al. (2010) and Frossard et al. (2011), who identified a dominant combustion source for OA at Barrow on the basis of correlations with combustion tracers. Shaw et al. (2010) attributed most OA at Barrow in winter to oceanic emissions but we find otherwise.

\section{BC deposition in the Arctic and implications for radiative forcing}

BC transported to the Arctic from mid-latitudes can be either removed by deposition or eventually ventilated out of the Arctic. We find in model sensitivity simulations that $\mathrm{BC}$ transported to the Arctic below $2 \mathrm{~km}$ is mostly deposited within the Arctic, whereas BC transported to the Arctic at higher altitudes is mostly ventilated out. Wet processes in our model account for $85-91 \%$ of total BC deposition to the Arctic in winter-spring. This is higher than in the previous model studies of Huang et al. (2010) and Liu et al. (2011), but consistent with the studies of Flanner et al. (2007). Spackman et al. (2010) inferred a dry deposition flux for BC of 100 $5300 \mathrm{ng} \mathrm{m}^{-2}$ day $^{-1}$ over snow/ice during ARCPAC on the basis of observed $\mathrm{BC}$ depletion in the boundary layer. Our computed dry deposition flux in the Western Arctic (mostly covered by snow/ice) is about $1500 \mathrm{ng} \mathrm{m}^{-2}$ day $^{-1}$ in spring, consistent with that estimate.
Figure 11 shows the spatial distribution of model BC total deposition in winter (Jan-Mar) and spring (Apr-May) 2008, separately for open fire and anthropogenic contributions. Maximum deposition is in the Eurasian sector due to Russian and European anthropogenic sources, augmented in spring by Russian fires. The fires double BC deposition to the Arctic in spring relative to winter. The Asian anthropogenic contribution to BC deposition is small in winter compared to European and Russian sources but becomes comparable to these sources in the spring.

While ARCTAS data only provide information for the North American Arctic, larger BC deposition in the Eurasian sector is consistent with the work of Doherty et al. (2010), who reported snow BC concentrations from a network of Russian and North American Arctic sites in Mar-May 20072009. We compared these observations (http://www.atmos. washington.edu/sootinsnow/) to model values for the corresponding years, using the GFEDv2 fire inventory for 2007 (van der Werf et al., 2006) and the FLAMBE inventory with above scaling factors for 2009. Figure 12 shows model results for the BC content of snow in winter (Jan-Mar) and spring (Apr-May) 2007-2009, as calculated from the ratio of $\mathrm{BC}$ to water deposition fluxes, and Fig. 13 compares to the Doherty et al. (2010) observations for individual sites and months. The observations show mean values of $11 \pm 5 \mathrm{ng} \mathrm{g}^{-1}$ at the North American sites and $23 \pm 16 \mathrm{ng} \mathrm{g}^{-1}$ at the Russian sites, and the corresponding model values for these sites and months are $11 \pm 3 \mathrm{ng} \mathrm{g}^{-1}$ and $31 \pm 11 \mathrm{ng} \mathrm{g}^{-1}$. Excluding the outlier with observed value of $30 \mathrm{ng} \mathrm{g}^{-1}$ in 2007, we find a good model-observed correlation at North American sites with $r=0.60$. Russian data are too sparse to evaluate a correlation. Spackman et al. (2010) extrapolated the BC dry deposition fluxes inferred from their aircraft data to BC content in snow and found consistency with the data of Doherty et al. (2010), in apparent contradiction with our model results where wet deposition dominates. However, the snowfall used by Spackman et al. (2010) in their calculation is only $20 \%$ of that used in our model from the GEOS-5 data.

MODIS fire counts show that spring 2007 had lower-thanaverage Russian fires while 2009 was near average, offering a contrast to spring 2008 which had anomalously high Russian fire activity (http://disc.sci.gsfc.nasa.gov/giovanni/). The total model BC deposition to the Arctic in April-May is $16 \mathrm{Gg}$ month $^{-1}$ for 2007 (including $13 \%$ from open fires), $41 \mathrm{Gg}$ month $^{-1}$ for $2008(61 \%)$, and $34 \mathrm{Gg}$ month $^{-1}$ for $2009(46 \%)$. Deposition in Jan-Mar has little interannual variability $\left(14-19 \mathrm{Gg}\right.$ month $\left.^{-1}\right)$. The relative contribution of dry deposition to total deposition is $15 \%$ in winter and $9 \%$ in spring, with little interannual variability. It is smallest over the Eurasian Arctic in spring where the deposition flux is highest.

Model source attribution shows that the mean contribution of open fires to the BC content in Arctic snow is $10 \%$ in winter and $60 \%$ in spring 2008 (40\% for springs 2007-2009). 


\section{Open fires}
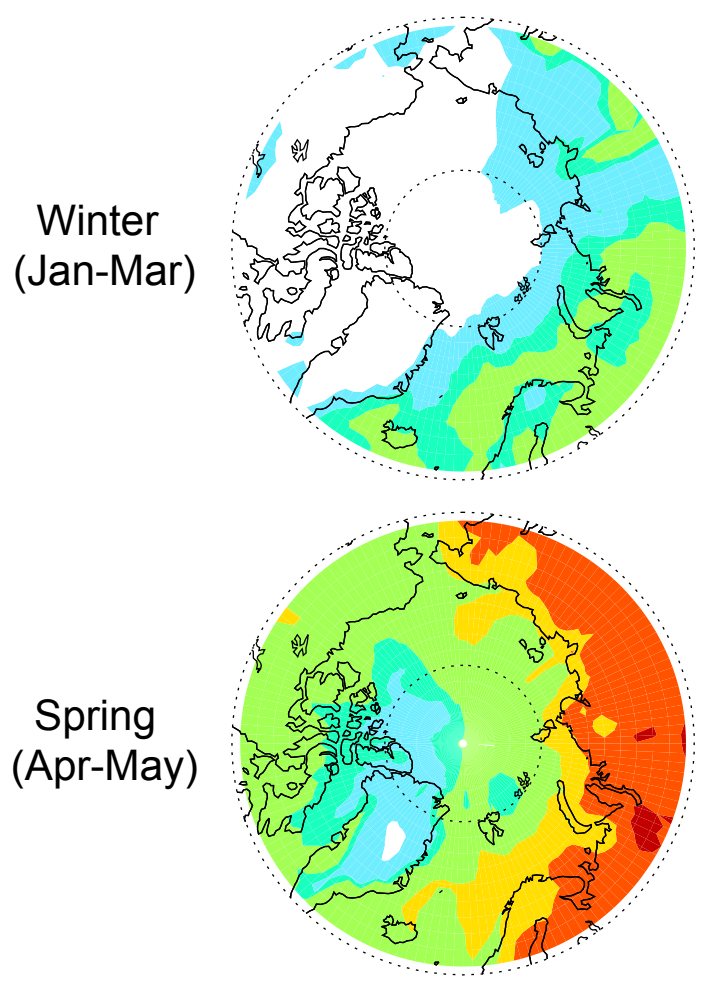

Anthropogenic
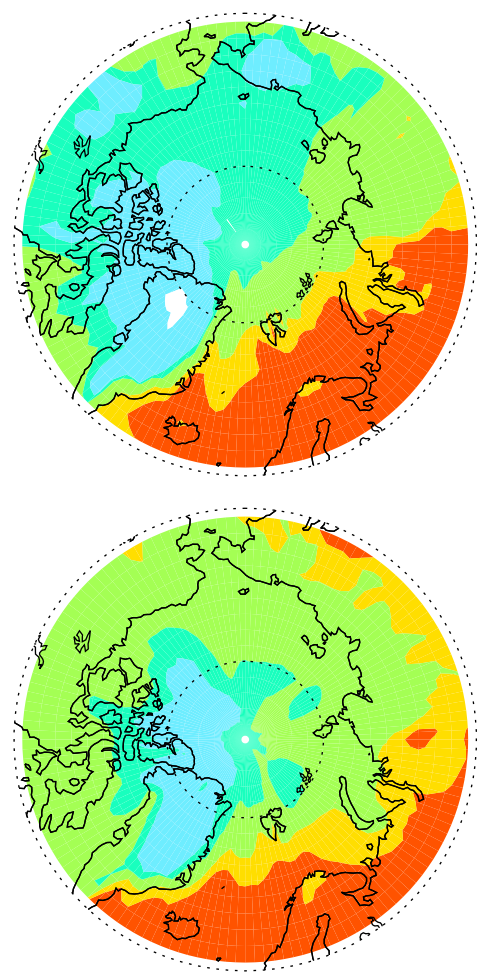

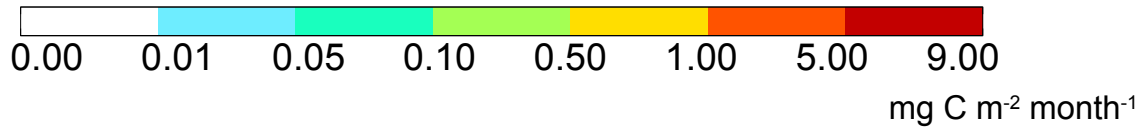

Fig. 11. Contributions of open fire and anthropogenic (fuel combustion) sources to the BC deposition flux in GEOS-Chem for winter and spring 2008.

Hegg et al. $(2009,2010)$ and Doherty et al. (2010) previously reported a dominant influence from biomass burning in their BC snow content data, based on absorption ?ngstrom exponents and correlation with biomass burning tracers. Part of the discrepancy could reflect biofuel combustion, which accounts in the model for $38 \%$ of annual anthropogenic emissions in Asia and $25 \%$ in Russia, and would be highest in winter-spring due to residential heating. In addition, mixing of anthropogenic and fire influences in Asian outflow discussed above complicates source attribution in the observations; this mixing is apparent in the Hegg et al. (2010) analysis as an association of sulfate with biomass burning influence.

Figure 14 shows model results for the decreases in snow albedo in winter (Jan-Mar) and spring (Apr-May) 2008 due to $\mathrm{BC}$ deposition to snow. We assume a constant snow grain radius of $100 \mu \mathrm{m}$ (McConnell et al., 2007) with no significant aging, and estimate the effect of BC on snow albedo based on Fig. 2 in Warren and Wiscombe (1995). The resulting decrease in snow albedo averaged over the Arctic is $0.4 \%$ in winter and $0.8 \%$ in spring $2008(0.6 \%$ for spring $2007-$
2009), lower than previous estimates of $1.1-4.7 \%$ (Park et al., 2005; Flanner et al., 2007; Koch et al., 2009a). By convolving this result with the GEOS-5 incoming solar radiation at the surface we deduce a surface radiative forcing over the Arctic (north of $60^{\circ} \mathrm{N}$ ) from deposited BC of $0.1 \mathrm{~W} \mathrm{~m}^{-2}$ in winter and $1.7 \mathrm{~W} \mathrm{~m}^{-2}$ in spring $2008\left(1.2 \mathrm{~W} \mathrm{~m}^{-2}\right.$ for spring 2007-2009, including $0.6 \mathrm{~W} \mathrm{~m}^{-2}$ from anthropogenic sources only). A previous model calculation by Flanner et al. (2007) reported a surface radiative forcing of $0.02 \mathrm{~W} \mathrm{~m}^{-2}$ in winter and $0.53 \mathrm{~W} \mathrm{~m}^{-2}$ in spring due to anthropogenic BC over the same domain, similar to our values.

\section{Comparison to previous global models}

Simulation of BC concentrations over the Arctic is considered a difficult problem for global models. Multi-model community (AerocCom and HTAP) intercomparisons show order-of magnitude differences between models and either negative (Shindell et al., 2008; Koch et al., 2009b) or positive bias (Schwarz et al., 2010) compared with observations. 


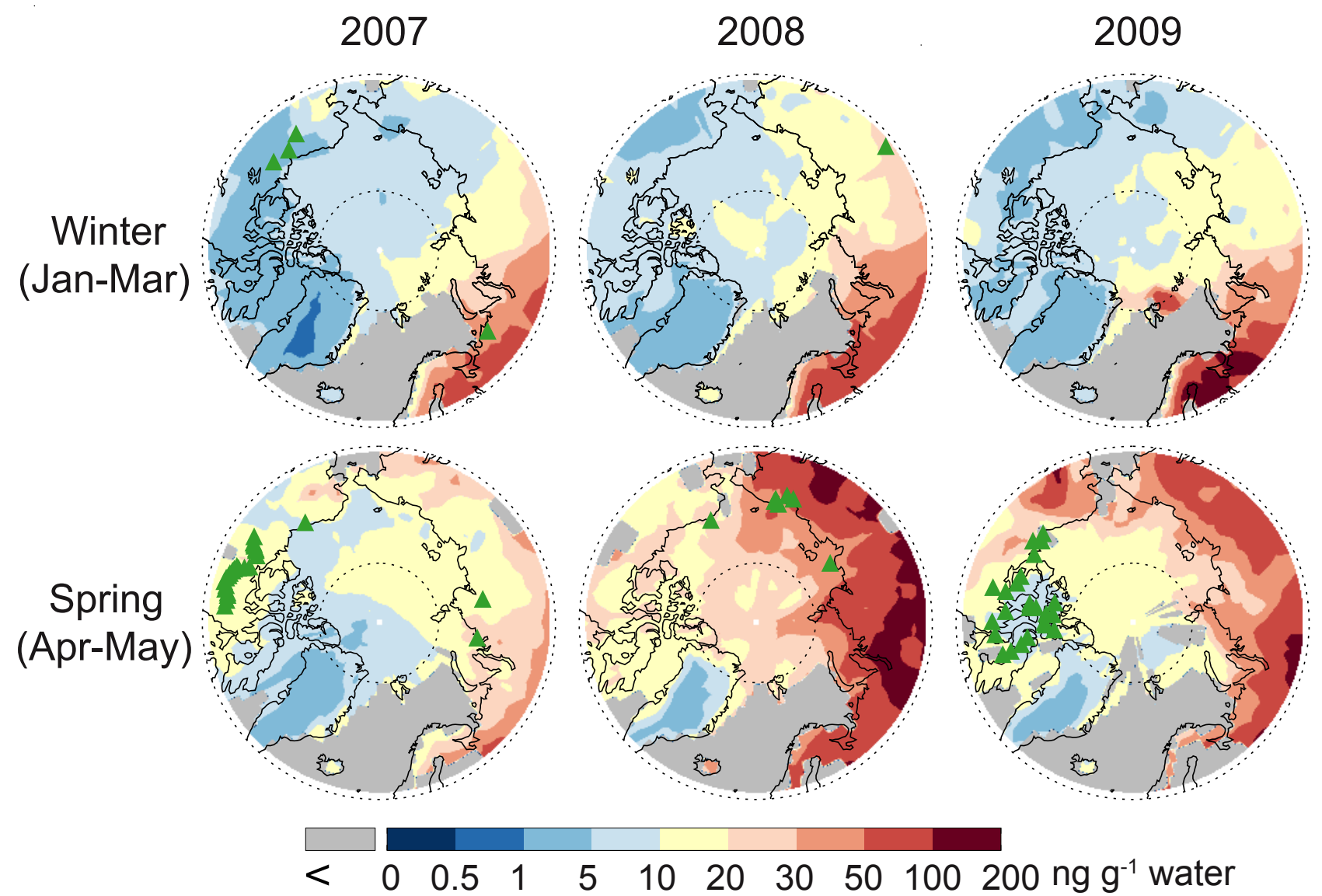

Fig. 12. Simulated BC content of Arctic snow in winter and spring 2007-2009. Snow-free areas are shown in gray. Green triangles indicate snow sampling sites from Doherty et al. (2010) for the corresponding years and seasons.
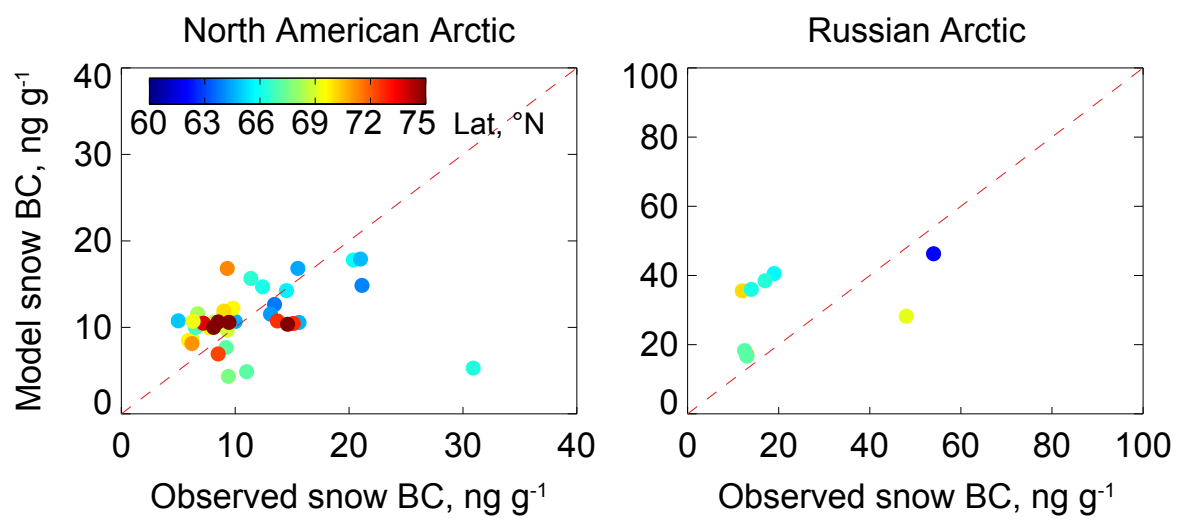

Fig. 13. Scatterplots of simulated vs. observed BC content in snow for North American and Russian Arctic sites in Mar-May 2007-2009 (Fig. 12). Observations from Doherty et al. (2010) are averaged over model grid squares, and model results are sampled for the month and year of observations. The data are colored by latitude. Also shown is the 1:1 line. 


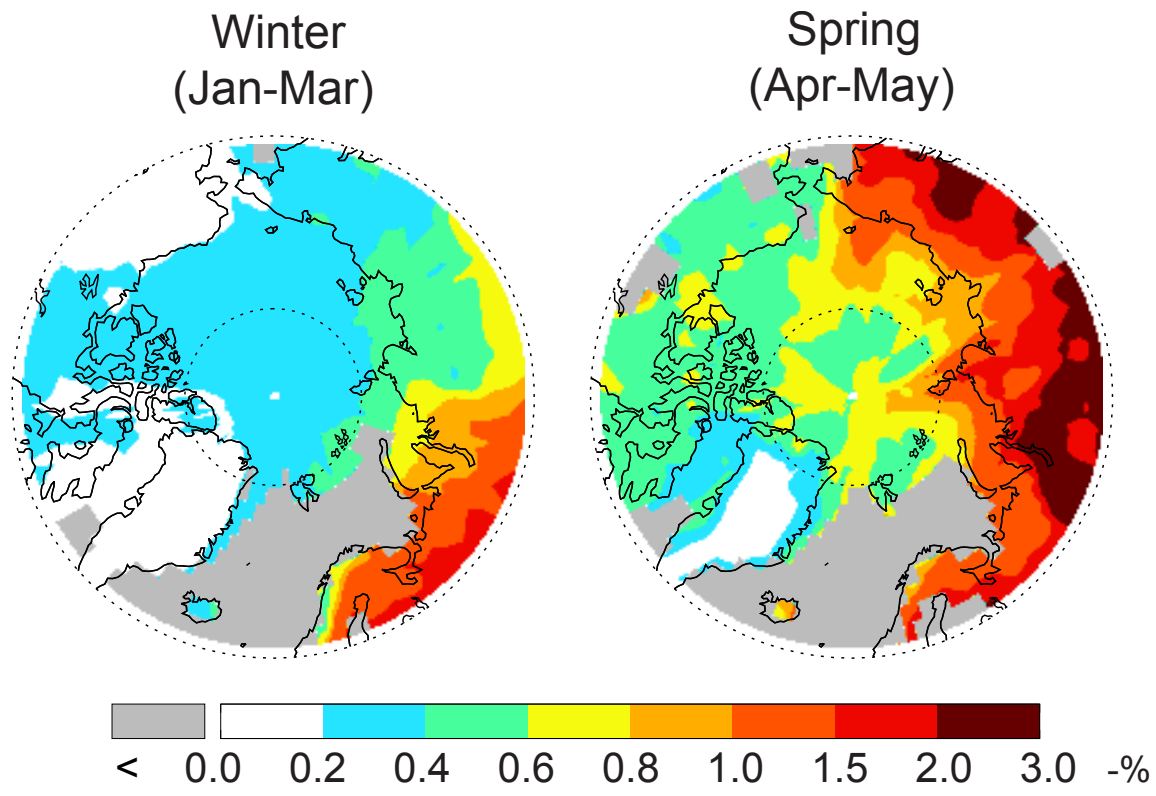

Fig. 14. Model decreases in snow albedo due to $\mathrm{BC}$ deposition in the Arctic $\left(>60^{\circ} \mathrm{N}\right)$ in winter and spring 2008 . Snow-free areas are shown in gray.

These differences between models reflect diversity in both emissions and scavenging efficiency. Considering our general success in reproducing the ensemble of BC observations over the Arctic, it is useful to reflect on what this success implies for modeling BC in that region.

It should be noted that the community intercomparisons cited above involved many models that were not previously evaluated in the Arctic. The order-of-magnitude differences between models may be explained by inadequate representations of wet scavenging, which is particularly important for modeling BC in the Arctic because of multiple e-folding loss during transport from northern mid-latitudes (Liu et al., 2011). Individual model studies targeting the Arctic demonstrate much better comparisons to BC observations (Koch and Hansen, 2005; Koch et al., 2009b; Huang et al., 2010; Liu et al., 2011), with our evaluation being the most extensive by encompassing surface air, aircraft, and snow observations. Huang et al. (2010) show good comparisons to observed BC concentrations in surface air while Koch and Hansen (2005) and Liu et al. (2011) reproduce the seasonality but still underestimate the winter-spring maximum by a factor of 2-3. Comparisons to ARCTAS vertical profiles show slight underestimation in Koch et al. (2009b) and no significant bias in Liu et al. (2011).

Table 2 lists the BC sources and global lifetime used by the above models in comparison to ours. Our global anthropogenic emissions are close to Huang et al. (2010) but about $50 \%$ higher than others, reflecting the major increase in Asian emissions since 2000. Our fire emissions are the highest, though this is mainly weighted by the tropics (Ta- ble 1) and has little influence on the Arctic. Our Russian fire emissions are high $\left(0.6 \mathrm{Tg} \mathrm{Ca}^{-1}\right.$, as compared to $0.3 \mathrm{Tg} \mathrm{a}^{-1}$ in Koch and Hansen (2005) and Huang et al. (2010)), but this reflects the anomalous 2008 fire season (Fisher et al., 2010). Koch and Hansen (2005) implied that their low model bias might be explained by underestimate of Asian anthropogenic emissions.

Our global mean lifetime of BC against deposition (5.9 days) is $20-40 \%$ shorter than in the other models of Table 2 , though within the 5-11 days of the ensemble of models intercompared by Koch et al. (2009b). The global lifetime is of limited relevance to simulation of the Arctic in winter-spring, where scavenging is principally from cold clouds and snow. There the different models exhibit complicated differences in their scavenging parameterizations. In our model, scavenging from cold clouds is restricted to hydrophobic BC; it is efficient in source regions but inefficient in the Arctic because $\mathrm{BC}$ becomes hydrophilic after an aging time of 1 day. The other models in Table 2 scavenge hydrophilic BC from cold clouds but not hydrophobic BC. Liu et al. (2011) increased the atmospheric lifetime of $\mathrm{BC}$ in their simulation for the Arctic by making the conversion from hydrophobic to hydrophilic contingent on $\mathrm{OH}$ levels (as opposed to a fixed 1-day time scale in our model and most others). Below-cloud scavenging from large-scale precipitation removes both hydrophobic and hydrophilic BC in most models in Table 2 except Huang et al. (2010), which does not scavenge hydrophobic BC at all. In our model, below-cloud scavenging by snow is much more efficient than by rain because of the larger cross sectional area of snow crystals vs. raindrops. Huang 
Table 2. Global model representations of atmospheric BC.

\begin{tabular}{llrrr}
\hline \multirow{2}{*}{ Reference } & Model & \multicolumn{2}{c}{ Global source, TgCa $^{-1}$} & Lifetime $^{\mathrm{b}}$, \\
\cline { 3 - 3 } & & Anthropogenic & Open fires & days \\
\hline This work & GEOS-Chem & 7.0 & 11 & 5.9 \\
Liu et al. (2011) & AM3 & 5.1 & 2.6 & 9.5 \\
Huang et al. (2010) & GEM-AQ & 6.0 & 4.9 & 9.2 \\
Koch et al. (2009b) & GISS & 4.4 & 2.8 & 9.2 \\
Koch and Hansen (2005) & GISS & 4.7 & 6.0 & 7.3 \\
\hline
\end{tabular}

${ }^{a}$ Including fossil and biofuel combustion

${ }^{\mathrm{b}}$ Global lifetime in the troposphere against deposition

et al. (2010) and Liu et al. (2011) also include higher belowcloud scavenging efficiency from snow than from rain.

Although dry deposition is a minor contributor to atmospheric removal of Arctic BC, it can significantly affect surface air concentrations. Of most relevance is the deposition to snow/ice. The standard GEOS-Chem model using the resistance-in-series parameterization of Wesely (1989) has a mean dry deposition velocity over snow/ice of $0.08 \mathrm{~cm} \mathrm{~s}^{-1}$, which would cause underestimate of observed Arctic surface air concentrations for BC and also sulfate (Fisher et al., 2011). In our work and that of Fisher et al. (2011), the dry deposition velocity of $\mathrm{BC}$ over snow/ice is fixed at $0.03 \mathrm{~cm} \mathrm{~s}^{-1}$, based on the observations of Nilsson and Rannik (2001) and Held et al. (2011), and this corrects the underestimate. Liu et al. (2011) used a value of $0.04-0.07 \mathrm{~cm} \mathrm{~s}^{-1}$ over snow/ice. The other studies in Table 2 used standard resistance-in-series parameterizations but did not report their dry deposition velocities.

\section{Conclusions}

We used the GEOS-Chem chemical transport model (CTM) to interpret aircraft observations of black carbon (BC) and organic aerosol (OA) from the NASA ARCTAS campaign over the North American Arctic in April 2008, as well as longer-term observations of $\mathrm{BC}$ concentrations in surface air and in snow. Our focus was to quantify the contributions of different source types and source regions to Arctic BC and $\mathrm{OA}$ concentrations in winter-spring, the role of deposition processes, the resulting source attribution for $\mathrm{BC}$ in snow, and the implications for radiative forcing.

Our GEOS-Chem simulation includes an improved representation of aerosol scavenging by cold clouds and by snow, anthropogenic (fossil fuel and biofuel) emissions of BC and OA from the Bond et al. (2007) inventory for 2000, and open fire emissions from the FLAMBE inventory of Reid et al. (2009) with hourly resolution. We evaluated BC sources from the northern mid-latitude continents with data from observation networks. We find that Russian and Asian anthropogenic emissions have to be doubled from Bond et al. (2007) to improve agreement with BC observations, as might be expected from increasing fuel use in these regions since 2000. Unusually large fires occurred in Russia in April 2008. FLAMBE estimates of biomass burned for these fires had to be decreased as previously shown by Fisher et al. (2010) from ARCTAS and satellite CO data. We find that $\mathrm{BC}$ and $\mathrm{OA}$ fire emission factors of 0.87 and $6.8 \mathrm{~g}$ carbon per $\mathrm{kg}$ dry mass burned, respectively, give a good simulation of observed Russian fire plumes.

The resulting model provides a good fit to the mean observed concentrations and vertical gradients of $\mathrm{BC}$ and OA along the ARCTAS flight tracks. Considering that the sources in the model are independently constrained by comparisons to observations over northern mid-latitude continents and in fire plumes, the successful simulation of the ARCTAS data provides some support for the model representation of aerosol deposition. Open fires account for most of OA in the model while anthropogenic emissions are more important for BC. Model and observations show strong peaks in the mid-troposphere for both $\mathrm{BC}$ and $\mathrm{OA}$, reflecting the transport of Russian fire and Asian anthropogenic effluents lifted by warm conveyor belts (WCBs). Open fires contribute $46 \%$ of $\mathrm{BC}$ and $84 \%$ of OA in the mid-troposphere $(2-6 \mathrm{~km})$ in the model. Near the surface $(<1 \mathrm{~km})$, by contrast, fires contribute only $20 \%$ of BC and $60 \%$ of OA. Anthropogenic $\mathrm{BC}$ concentrations in the mid-troposphere are mostly of Asian origin, but in surface air we find comparable contributions from North America, Europe and Russia. These model source attributions are consistent with observed correlations of $\mathrm{BC}$ and $\mathrm{OA}$ with acetonitrile (a tracer of biomass burning) and with comparisons of simulated and observed correlations of $\mathrm{BC}$ and $\mathrm{OA}$ vs. sulfate.

Expanding the model results to the scale of the Arctic polar cap in April 2008 indicates that open fire emissions contribute $50 \%$ of total BC in the Arctic tropospheric column and $81 \%$ of total OA. We find the strongest fire influences in the Eurasian Arctic. Our relatively higher model Asian 
contribution to Arctic BC in spring compared with previous studies (Koch and Hansen, 2005; Shindell et al., 2008; Tilmes et al., 2011) reflects our higher Asian emission inventory, constrained by observations at Chinese sites.

We used surface air observations of $\mathrm{BC}$ and $\mathrm{OA}$ at two Alaskan sites (Denali and Barrow) in Jan-May 2007-2009 to place the aircraft data in a broader seasonal context. The Denali site shows an increase of BC from winter to spring due to Russian fire and Asian pollution influences. The seasonality is reversed at Barrow with a winter maximum that we attribute to transport from Russia. OA concentrations at Denali and Barrow are well simulated by the model, with similar sources as for BC but with stronger impact of fire emissions in spring.

Spring 2008 was anomalously affected by Russian fires. We conducted simulations for Jan-May 2007-2009 to obtain an interannual perspective and to evaluate the model with a pan-Arctic network of observations of BC snow content (Doherty et al., 2010). We find in the model that the total BC deposition flux to the Arctic in 2007-2009 averages 17 (1419) $\mathrm{Gg}_{\text {month }}{ }^{-1}$ in Jan-Mar and 30 (16-41) Gg month $^{-1}$ in Apr-May, where the range indicates the interannual variability. Higher deposition fluxes in spring are due to fires. The $\mathrm{BC}$ content of snow is highest in the Eurasian Arctic, consistent with the Doherty et al. (2010) data.

Open fires in the model account on average for $10 \%$ of BC content in Arctic snow in Jan-Mar and $40 \%$ in AprMay 2007-2009. Hegg et al. $(2009,2010)$ and Doherty et al. (2010) previously inferred a dominant biomass burning influence at most of their Arctic sites on the basis of correlations with tracers and absorption 'Ångstrom exponents. Some of that difference can be reconciled by the biofuel source of BC, which they would diagnose as biomass burning but must be viewed as anthropogenic. In addition, the well-known mixing of anthropogenic and fire influences in Asian outflow could result in anthropogenic influences being correlated with biomass burning tracers.

We estimate decreases in snow albedo due to BC deposition in 2007-2009 of $0.4 \%$ in winter and $0.6 \%$ in spring. The resulting mean surface radiative forcing over the Arctic in spring is $1.2 \mathrm{~W} \mathrm{~m}^{-2}$ (including open fires) and $0.6 \mathrm{~W} \mathrm{~m}^{-2}$ (anthropogenic only). This is consistent with the anthropogenic value of $0.53 \mathrm{~W} \mathrm{~m}^{-2}$ previously reported by Flanner et al. (2007) for the same region.

Acknowledgements. This work was funded by the Decadal and Regional Climate Prediction using Earth System Models (EaSM) Program of the US National Science Foundation. MJC and JLJ were supported by NASA grant NNX08AD39G.

Edited by: P. Quinn

\section{References}

Aiken, A. C., DeCarlo, P. F., Kroll, J. H., Worsnop, D. R., Huffman, J. A., Docherty, K. S., Ulbrich, I. M., Mohr, C., Kimmel, J. R., Sueper, D., Sun, Y., Zhang, Q., Trimborn, A., Northway, M., Ziemann, P. J., Canagaratna, M. R., Onasch, T. B., Alfarra, M. R., Prevot, A. S. H., Dommen, J., Duplissy, J., Metzger, A., Baltensperger, U., and Jimenez, J. L.: O/C and OM/OC ratios of primary, secondary, and ambient organic aerosols with highresolution time-of-flight aerosol mass spectrometry, Environ. Sci. Technol., 42, 4478-4485, doi:10.1021/es703009q, 2008.

Akagi, S. K., Yokelson, R. J., Wiedinmyer, C., Alvarado, M. J., Reid, J. S., Karl, T., Crounse, J. D., and Wennberg, P. O.: Emission factors for open and domestic biomass burning for use in atmospheric models, Atmos. Chem. Phys., 11, 4039-4072, doi:10.5194/acp-11-4039-2011, 2011.

Amos, H. M., Jacob, D. J., Holmes, C. D., Fisher, J. A., Wang, Q., Yantosca, R. M., Corbitt, E. S., Galarneau, E., Rutter, A. P., Gustin, M. S., Steffen, A., Schauer, J. J., Graydon, J. A., Louis, V. L. S., Talbot, R. W., Edgerton, E. S., and Sunderland, E. M.: Gas-particle partitioning of atmospheric $\mathrm{Hg}$ (II) and its effect on global mercury deposition, Atmos. Chem. Phys. Discuss., 11, 29441-29477, doi:10.5194/acpd-11-29441-2011, 2011.

Andreae, M. O. and Merlet, P.: Emission of trace gases and aerosols from biomass burning, Glob. Biogeochem. Cy., 15, 955-966, 2001.

Andreae, M. O. and Rosenfeld, D.: Aerosol-cloudprecipitation interactions. Part 1 . The nature and sources of cloud-active aerosols, Earth-Sci. Rev., 89, 13-41, doi:10.1016/j.earscirev.2008.03.001, 2008

Barrie, L. A., Hoff, R. M., and Daggupaty, S. M.: The influence of mid-latitudinal pollution sources on haze in the canadian arctic, Atmos. Environ., 15, 1407-1419, 1981.

Baumgardner, D., Subramanian, R., Twohy, C., Stith, J., and Kok, G.: Scavenging of black carbon by ice crystals over the northern Pacific, Geophys. Res. Lett., 35, L22815, doi:10.1029/2008GL035764, 2008.

Bey, I., Jacob, D. J., Logan, J. A., and Yantosca, R. M.: Asian chemical outflow to the Pacific in spring: Origins, pathways, and budgets, J. Geophys. Res.-Atmos., 106, 23097-23113, 2001.

Bond, T. C., Bhardwaj, E., Dong, R., Jogani, R., Jung, S. K., Roden, C., Streets, D. G., and Trautmann, N. M.: Historical emissions of black and organic carbon aerosol from energy-related combustion, 1850-2000, Glob. Biogeochem. Cy., 21, Gb2018, doi:10.1029/2006GB002840, 2007.

Brock, C. A., Cozic, J., Bahreini, R., Froyd, K. D., Middlebrook, A. M., McComiskey, A., Brioude, J., Cooper, O. R., Stohl, A., Aikin, K. C., de Gouw, J. A., Fahey, D. W., Ferrare, R. A., Gao, R. S., Gore, W., Holloway, J. S., Hubler, G., Jefferson, A., Lack, D. A., Lance, S., Moore, R. H., Murphy, D. M., Nenes, A., Novelli, P. C., Nowak, J. B., Ogren, J. A., Peischl, J., Pierce, R. B., Pilewskie, P., Quinn, P. K., Ryerson, T. B., Schmidt, K. S., Schwarz, J. P., Sodemann, H., Spackman, J. R., Stark, H., Thomson, D. S., Thornberry, T., Veres, P., Watts, L. A., Warneke, C., and Wollny, A. G.: Characteristics, sources, and transport of aerosols measured in spring 2008 during the aerosol, radiation, and cloud processes affecting Arctic Climate (ARCPAC) Project, Atmos. Chem. Phys., 11, 2423-2453, doi:10.5194/acp-11-24232011, 2011.

Chen, Y. L., Kreidenweis, S. M., McInnes, L. M., Rogers, D. C., and 
DeMott, P. J.: Single particle analyses of ice nucleating aerosols in the upper troposphere and lower stratosphere, Geophys. Res. Lett., 25, 1391-1394, 1998.

Chung, S. H. and Seinfeld, J. H.: Global distribution and climate forcing of carbonaceous aerosols, J. Geophys. Res.-Atmos., 107, 4407, doi:10.1029/2001JD001397, 2002.

Cooke, W. F., Liousse, C., Cachier, H., and Feichter, J.: Construction of a 1 degrees $\times 1$ degrees fossil fuel emission data set for carbonaceous aerosol and implementation and radiative impact in the ECHAM4 model, J. Geophys. Res.-Atmos., 104, 2213722162, 1999.

Cozic, J., Verheggen, B., Mertes, S., Connolly, P., Bower, K., Petzold, A., Baltensperger, U., and Weingartner, E.: Scavenging of black carbon in mixed phase clouds at the high alpine site Jungfraujoch, Atmos. Chem. Phys., 7, 1797-1807, doi:10.5194/acp-7-1797-2007, 2007.

Cozic, J., Mertes, S., Verheggen, B., Cziczo, D. J., Gallavardin, S. J., Walter, S., Baltensperger, U., and Weingartner, E.: Black carbon enrichment in atmospheric ice particle residuals observed in lower tropospheric mixed phase clouds, J. Geophys. Res.Atmos., 113, D15209, doi:10.1029/2007JD009266, 2008.

Croft, B., Lohmann, U., Martin, R. V., Stier, P., Wurzler, S., Feichter, J., Posselt, R., and Ferrachat, S.: Aerosol size-dependent below-cloud scavenging by rain and snow in the ECHAM5HAM, Atmos. Chem. Phys., 9, 4653-4675, doi:10.5194/acp-94653-2009, 2009.

Dana, M. T. and Hales, J. M.: Statistical aspects of washout of polydisperse aerosols, Atmos. Environ., 10, 45-50, 1976.

DelGenio, A. D., Yao, M. S., Kovari, W., and Lo, K. K. W.: A prognostic cloud water parameterization for global climate models, J. Climate., 9, 270-304, 1996.

Djupstrom, M., Pacyna, J. M., Maenhaut, W., Winchester, J. W., Li, S. M., and Shaw, G. E.: Contamination of arctic air at 3 sites during a haze event in late winter 1986, Atmos. Environ. A-Gen., 27, 2999-3010, 1993.

Doherty, S. J., Warren, S. G., Grenfell, T. C., Clarke, A. D., and Brandt, R. E.: Light-absorbing impurities in Arctic snow, Atmos. Chem. Phys., 10, 11647-11680, doi:10.5194/acp-1011647-2010, 2010.

Dunlea, E. J., DeCarlo, P. F., Aiken, A. C., Kimmel, J. R., Peltier, R. E., Weber, R. J., Tomlison, J., Collins, D. R., Shinozuka, Y., McNaughton, C. S., Howell, S. G., Clarke, A. D., Emmons, L. K., Apel, E. C., Pfister, G. G., van Donkelaar, A., Martin, R. V., Millet, D. B., Heald, C. L., and Jimenez, J. L.: Evolution of Asian aerosols during transpacific transport in INTEX-B, Atmos. Chem. Phys. Discuss., 8, 15375-15461, doi:10.5194/acpd8-15375-2008, 2008.

Eleftheriadis, K., Vratolis, S., and Nyeki, S.: Aerosol black carbon in the European Arctic: Measurements at Zeppelin station, Ny-Alesund, Svalbard from 1998-2007, Geophys. Res. Lett., 36, L02809, doi:10.1029/2008GL035741, 2009.

Feng, J.: A 3-mode parameterization of below-cloud scavenging of aerosols for use in atmospheric dispersion models, Atmos. Environ., 41, 6808-6822, doi:10.1016/j.atmosenv.2007.04.046, 2007.

Feng, J.: A size-resolved model for below-cloud scavenging of aerosols by snowfall, J. Geophys. Res.-Atmos., 114, D08203, doi:10.1029/2008JD011012, 2009.

Fisher, J. A., Jacob, D. J., Purdy, M. T., Kopacz, M., Le Sager, P., Carouge, C., Holmes, C. D., Yantosca, R. M., Batchelor,
R. L., Strong, K., Diskin, G. S., Fuelberg, H. E., Holloway, J. S., Hyer, E. J., McMillan, W. W., Warner, J., Streets, D. G., Zhang, Q., Wang, Y., and Wu, S.: Source attribution and interannual variability of Arctic pollution in spring constrained by aircraft (ARCTAS, ARCPAC) and satellite (AIRS) observations of carbon monoxide, Atmos. Chem. Phys., 10, 977-996, doi:10.5194/acp-10-977-2010, 2010.

Fisher, J. A., Jacob, D. J., Wang, Q., Bahreini, R., Carouge, C. C., Cubison, M. J., Dibb, J. E., Diehl, T., Jimenez, J. L., Leibensperger, E. M., Lu, Z., Meinders, M. B. J., Pye, H. O. T., Quinn, P. K., Sharma, S., Streets, D.G., van Donkelaar, A., and Yantosca, R. M.: Sources, distribution, and acidity of sulfateammonium aerosol in the Arctic in winter-spring, Atmos. Environ., 45, 7301-7318, doi:10.1016/j.atmosenv.2011.08.030, 2011.

Flanner, M. G., Zender, C. S., Randerson, J. T., and Rasch, P. J.: Present-day climate forcing and response from black carbon in snow, J. Geophys. Res.-Atmos., 112, D11202, doi:10.1029/2006JD008003, 2007.

Frossard, A. A., Shaw, P. M., Russell, L. M., Kroll, J. H., Canagaratna, M. R., Worsnop, D. R., Quinn, P. K., and Bates, T. S.: Springtime Arctic haze contributions of submicron organic particles from European and Asian combustion sources, J. Geophys. Res.-Atmos., 116, D05205, doi:10.1029/2010JD015178, 2011.

Fu, T. M., Jacob, D. J., Wittrock, F., Burrows, J. P., Vrekoussis, M., and Henze, D. K.: Global budgets of atmospheric glyoxal and methylglyoxal, and implications for formation of secondary organic aerosols, J. Geophys. Res.-Atmos., 113, D15303, doi:10.1029/2007JD009505, 2008.

Fu, T. M., Jacob, D. J., and Heald, C. L.: Aqueous-phase reactive uptake of dicarbonyls as a source of organic aerosol over eastern North America, Atmos. Environ., 43, 1814-1822, doi:10.1016/j.atmosenv.2008.12.029, 2009.

Giorgi, F. and Chameides, W. L.: Rainout lifetimes of highly soluble aerosols and gases as inferred from simulations with a general-circulation model, J. Geophys. Res.-Atmos., 91, 1436714376, 1986.

Gong, S. L., Zhao, T. L., Sharma, S., Toom-Sauntry, D., Lavoue, D., Zhang, X. B., Leaitch, W. R., and Barrie, L. A.: Identification of trends and interannual variability of sulfate and black carbon in the Canadian High Arctic: 1981-2007, J. Geophys. Res.-Atmos., 115, D07305, doi:10.1029/2009JD012943, 2010.

Hansen, A. D. A. and Novakov, T.: Aerosol black carbon measurements in the Arctic haze during AGASP-II, J. Atmos. Chem., 9, 347-361, doi:10.1007/bf00052842, 1989.

Hansen, A. D. A. and Rosen, H.: Vertical distributions of particulate carbon, sulfur, and bromine in the arctic haze and comparison with ground-level measurements at barrow, alaska, Geophys. Res. Lett., 11, 381-384, doi:10.1029/GL011i005p00381, 1984.

Hansen, A. D. A., Conway, T. J., Strele, L. P., Bodhaine, B. A., Thoning, K. W., Tans, P., and Novakov, T.: Correlations among combustion effluent species at Barrow, Alaska: Aerosol black carbon, carbon dioxide, and methane, J. Atmos. Chem., 9, 283299, doi:10.1007/bf00052838, 1989.

Heald, C. L., Jacob, D. J., Park, R. J., Russell, L. M., Huebert, B. J., Seinfeld, J. H., Liao, H., and Weber, R. J.: A large organic aerosol source in the free troposphere missing from current models, Geophys. Res. Lett., 32, L18809, doi:10.1029/2005g1023831, 2005.

Heald, C. L., Coe, H., Jimenez, J. L., Weber, R. J., Bahreini, R., 
Middlebrook, A. M., Russell, L. M., Jolleys, M., Fu, T. M., Allan, J. D., Bower, K. N., Capes, G., Crosier, J., Morgan, W. T., Robinson, N. H., Williams, P. I., Cubison, M. J., DeCarlo, P. F., and Dunlea, E. J.: Exploring the vertical profile of atmospheric organic aerosol: comparing 17 aircraft field campaigns with a global model, Atmos. Chem. Phys. Discuss., 11, 25371-25425, doi:10.5194/acpd-11-25371-2011, 2011.

Hegg, D. A., Warren, S. G., Grenfell, T. C., Doherty, S. J., Larson, T. V., and Clarke, A. D.: Source attribution of black carbon in arctic snow, Environ. Sci. Technol., 43, 4016-4021, doi:10.1021/es803623f, 2009.

Hegg, D. A., Warren, S. G., Grenfell, T. C., Doherty, S. J., and Clarke, A. D.: Sources of light-absorbing aerosol in arctic snow and their seasonal variation, Atmos. Chem. Phys., 10, 1092310938, doi:10.5194/acp-10-10923-2010, 2010.

Held, A., Orsini, D. A., Vaattovaara, P., Tjernström, M., and Leck, C.: Near-surface profiles of aerosol number concentration and temperature over the Arctic Ocean, Atmos. Meas. Tech. Discuss., 4, 3017-3053, doi:10.5194/amtd-4-3017-2011, 2011.

Henze, D. K. and Seinfeld, J. H.: Global secondary organic aerosol from isoprene oxidation, Geophys. Res. Lett., 33, L09812, doi:10.1029/2006GL025976, 2006.

Henze, D. K., Seinfeld, J. H., Ng, N. L., Kroll, J. H., Fu, T. M., Jacob, D. J., and Heald, C. L.: Global modeling of secondary organic aerosol formation from aromatic hydrocarbons: high- vs. low-yield pathways, Atmos. Chem. Phys., 8, 2405-2420, 2008, http://www.atmos-chem-phys.net/8/2405/2008/.

Hirdman, D., Burkhart, J. F., Sodemann, H., Eckhardt, S., Jefferson, A., Quinn, P. K., Sharma, S., Strom, J., and Stohl, A.: Longterm trends of black carbon and sulphate aerosol in the Arctic: changes in atmospheric transport and source region emissions, Atmos. Chem. Phys., 10, 9351-9368, doi:10.5194/acp-10-93512010, 2010.

Hodzic, A., Jimenez, J. L., Madronich, S., Canagaratna, M. R., DeCarlo, P. F., Kleinman, L., and Fast, J.: Modeling organic aerosols in a megacity: Potential contribution of semi-volatile and intermediate volatility primary organic compounds to secondary organic aerosol formation, Atmos. Chem. Phys., 10, 5491-5514, doi:10.5194/acp-10-5491-2010, 2010.

Holmes, C. D., Jacob, D. J., Corbitt, E. S., Mao, J., Yang, X., Talbot, R., and Slemr, F.: Global atmospheric model for mercury including oxidation by bromine atoms, Atmos. Chem. Phys., 10, 12037-12057, doi:10.5194/acp-10-12037-2010, 2010.

Huang, L., Gong, S. L., Jia, C. Q., and Lavoue, D.: Importance of deposition processes in simulating the seasonality of the Arctic black carbon aerosol, J. Geophys. Res.-Atmos., 115, D17207, doi:10.1029/2009JD013478, 2010.

IEA: Energy Statistics of Non-OECD Countries 2010, OECD Publishing, Paris, France, 2010.

Jacob, D. J., Crawford, J. H., Maring, H., Clarke, A. D., Dibb, J. E., Emmons, L. K., Ferrare, R. A., Hostetler, C. A., Russell, P. B., Singh, H. B., Thompson, A. M., Shaw, G. E., McCauley, E., Pederson, J. R., and Fisher, J. A.: The arctic research of the composition of the troposphere from aircraft and satellites (ARCTAS) mission: design, execution, and first results, Atmos. Chem. Phys., 10, 5191-5212, doi:10.5194/acp-10-5191-2010, 2010.

Jacobson, M. Z.: Strong radiative heating due to the mixing state of black carbon in atmospheric aerosols, Nature, 409, 695-697, 2001.
Jimenez, J. L., Jayne, J. T., Shi, Q., Kolb, C. E., Worsnop, D. R., Yourshaw, I., Seinfeld, J. H., Flagan, R. C., Zhang, X. F., Smith, K. A., Morris, J. W., and Davidovits, P.: Ambient aerosol sampling using the Aerodyne Aerosol Mass Spectrometer, J. Geophys. Res., 108, 8425, doi:10.1029/2001jd001213, 2003.

Kärcher, B., Möhler, O., DeMott, P. J., Pechtl, S., and Yu, F.: Insights into the role of soot aerosols in cirrus cloud formation, Atmos. Chem. Phys., 7, 4203-4227, doi:10.5194/acp-7-4203-2007, 2007.

Kawamura, K., Kasukabe, H., and Barrie, L. A.: Source and reaction pathways of dicarboxylic acids, ketoacids and dicarbonyls in arctic aerosols: One year of observations, Atmos. Environ., 30, 1709-1722, 1996.

Klonecki, A., Hess, P., Emmons, L., Smith, L., Orlando, J., and Blake, D.: Seasonal changes in the transport of pollutants into the Arctic troposphere-model study, J. Geophys. Res.-Atmos., 108, 8367, doi:10.1029/2002JD002199, 2003.

Koch, D. and Hansen, J.: Distant origins of Arctic black carbon: A Goddard Institute for Space Studies ModelE experiment, J. Geophys. Res.-Atmos., 110, D04204, doi:10.1029/2004JD005296, 2005.

Koch, D., Bond, T. C., Streets, D., Unger, N., and van der Werf, G. R.: Global impacts of aerosols from particular source regions and sectors, J. Geophys. Res.-Atmos., 112, D02205, doi:10.1029/2005JD007024, 2007.

Koch, D., Menon, S., Del Genio, A., Ruedy, R., Alienov, I., and Schmidt, G. A.: Distinguishing aerosol impacts on climate over the past century, J. Climate, 22, 2659-2677, doi:10.1175/2008JCLI2573.1, 2009a.

Koch, D., Schulz, M., Kinne, S., McNaughton, C., Spackman, J. R., Balkanski, Y., Bauer, S., Berntsen, T., Bond, T. C., Boucher, O., Chin, M., Clarke, A., De Luca, N., Dentener, F., Diehl, T., Dubovik, O., Easter, R., Fahey, D. W., Feichter, J., Fillmore, D., Freitag, S., Ghan, S., Ginoux, P., Gong, S., Horowitz, L., Iversen, T., Kirkevg, A., Klimont, Z., Kondo, Y., Krol, M., Liu, X., Miller, R., Montanaro, V., Moteki, N., Myhre, G., Penner, J. E., Perlwitz, J., Pitari, G., Reddy, S., Sahu, L., Sakamoto, H., Schuster, G., Schwarz, J. P., Seland, Ø., Stier, P., Takegawa, N., Takemura, T., Textor, C., van Aardenne, J. A., and Zhao, Y.: Evaluation of black carbon estimations in global aerosol models, Atmos. Chem. Phys., 9, 9001-9026, doi:10.5194/acp-9-9001-2009, 2009b.

Kondo, Y., Matsui, H., Moteki, N., Sahu, L., Takegawa, N., Kajino, M., Zhao, Y., Cubison, M. J., Jimenez, J. L., Vay, S., Diskin, G. S., Anderson, B., Wisthaler, A., Mikoviny, T., Fuelberg, H. E., Blake, D. R., Huey, G., Weinheimer, A. J., Knapp, D. J., and Brune, W. H.: Emissions of black carbon, organic, and inorganic aerosols from biomass burning in North America and Asia in 2008, J. Geophys. Res.-Atmos., 116, D08204, doi:10.1029/2010JD015152, 2011.

Kristjansson, J. E., Iversen, T., Kirkevag, A., Seland, O., and Debernard, J.: Response of the climate system to aerosol direct and indirect forcing: Role of cloud feedbacks, J. Geophys. Res.Atmos., 110, D24206, doi:10.1029/2005JD006299, 2005.

Law, K. S. and Stohl, A.: Arctic air pollution: Origins and impacts, Science, 315, 1537-1540, doi:10.1126/science.1137695, 2007.

Leibensperger, E. M., Mickley, L. J., Jacob, D. J., Chen, W.-T., Seinfeld, J. H., Nenes, A., Adams, P. J., Streets, D. G., Kumar, N., and Rind, D.: Climatic effects of 1950-2050 changes 
in US anthropogenic aerosols - Part 1: Aerosol trends and radiative forcing, Atmos. Chem. Phys. Discuss., 11, 2408524125, doi:10.5194/acpd-11-24085-2011, 2011.

Liu, H. Y., Jacob, D. J., Bey, I., and Yantosca, R. M.: Constraints from $\mathrm{Pb}-210$ and $\mathrm{Be}-7$ on wet deposition and transport in a global three-dimensional chemical tracer model driven by assimilated meteorological fields, J. Geophys. Res.-Atmos., 106, 1210912128, 2001.

Liu, H. Y., Jacob, D. J., Bey, I., Yantosca, R. M., Duncan, B. N., and Sachse, G. W.: Transport pathways for Asian pollution outflow over the Pacific: Interannual and seasonal variations, J. Geophys. Res.-Atmos., 108, 8786, doi:10.1029/2002JD003102, 2003.

Liu, J. F., Fan, S. M., Horowitz, L. W., and Levy, H.: Evaluation of factors controlling long-range transport of black carbon to the Arctic, J. Geophys. Res., 116, D04307, doi:10.1029/2010jd015145, 2011.

Lu, Z., Streets, D. G., Zhang, Q., Wang, S., Carmichael, G. R., Cheng, Y. F., Wei, C., Chin, M., Diehl, T., and Tan, Q.: Sulfur dioxide emissions in China and sulfur trends in East Asia since 2000, Atmos. Chem. Phys., 10, 6311-6331, doi:10.5194/acp-106311-2010, 2010.

Mao, J., Jacob, D. J., Evans, M. J., Olson, J. R., Ren, X., Brune, W. H., St. Clair, J. M., Crounse, J. D., Spencer, K. M., Beaver, M. R., Wennberg, P. O., Cubison, M. J., Jimenez, J. L., Fried, A., Weibring, P., Walega, J. G., Hall, S. R., Weinheimer, A. J., Cohen, R. C., Chen, G., Crawford, J. H., McNaughton, C., Clarke, A. D., Jaeglé, L., Fisher, J. A., Yantosca, R. M., Le Sager, P., and Carouge, C.: Chemistry of hydrogen oxide radicals (HOx) in the Arctic troposphere in spring, Atmos. Chem. Phys., 10, 58235838, doi:10.5194/acp-10-5823-2010, 2010.

Matsui, H., Kondo, Y., Moteki, N., Takegawa, N., Sahu, L. K., Zhao, Y., Fuelberg, H. E., Sessions, W. R., Diskin, G., Blake, D. R., Wisthaler, A., and Koike, M.: Seasonal variation of the transport of black carbon aerosol from the Asian continent to the Arctic during the ARCTAS aircraft campaign, J. Geophys. Res.Atmos., 116, D05202, doi:10.1029/2010JD015067, 2011.

McNaughton, C. S., Clarke, A. D., Freitag, S., Kapustin, V. N., Kondo, Y., Moteki, N., Sahu, L., Takegawa, N., Schwarz, J. P., Spackman, J. R., Watts, L., Diskin, G., Podolske, J., Holloway, J. S., Wisthaler, A., Mikoviny, T., de Gouw, J., Warneke, C., Jimenez, J., Cubison, M., Howell, S. G., Middlebrook, A., Bahreini, R., Anderson, B. E., Winstead, E., Thornhill, K. L., Lack, D., Cozic, J., and Brock, C. A.: Absorbing aerosol in the troposphere of the Western Arctic during the 2008 ARCTAS/ARCPAC airborne field campaigns, Atmos. Chem. Phys., 11, 7561-7582, doi:10.5194/acp-11-7561-2011, 2011.

McConnell, J. R., Edwards, R., Kok, G. L., Flanner, M. G., Zender, C. S., Saltzman, E. S., Banta, J. R., Pasteris, D. R., Carter, M. M., and Kahl, J. D. W.: 20th-century industrial black carbon emissions altered arctic climate forcing, Science, 317, 1381-1384, doi:10.1126/science.1144856, 2007.

Murakami, M., Kimura, T., Magono, C., and Kikuchi, K.: Observations of precipitation scavenging for water-soluble particles, J. Meteorol. Soc. Jap., 61, 346-358, 1983.

Nilsson, E. D. and Rannik, U.: Turbulent aerosol fluxes over the Arctic Ocean 1. Dry deposition over sea and pack ice, J. Geophys. Res.-Atmos., 106, 32125-32137, 2001.

Park, R. J., Jacob, D. J., Chin, M., and Martin, R. V.: Sources of carbonaceous aerosols over the United States and implica- tions for natural visibility, J. Geophys. Res.-Atmos., 108, 4355, doi:10.1029/2002JD003190, 2003.

Park, R. J., Jacob, D. J., Palmer, P. I., Clarke, A. D., Weber, R. J., Zondlo, M. A., Eisele, F. L., Bandy, A. R., Thornton, D. C., Sachse, G. W., and Bond, T. C.: Export efficiency of black carbon aerosol in continental outflow: Global implications, J. Geophys. Res.-Atmos., 110, D11205, doi:10.1029/2004JD005432, 2005.

Park, R. J., Jacob, D. J., Kumar, N., and Yantosca, R. M.: Regional visibility statistics in the United States: Natural and transboundary pollution influences, and implications for the Regional Haze Rule, Atmos. Environ., 40, 5405-5423, doi:10.1016/j.atmosenv.2006.04.059, 2006.

Quinn, P. K., Miller, T. L., Bates, T. S., Ogren, J. A., Andrews, E., and Shaw, G. E.: A 3-year record of simultaneously measured aerosol chemical and optical properties at Barrow, Alaska, J. Geophys. Res.-Atmos., 107, 4130, doi:10.1029/2001JD001248, 2002.

Quinn, P. K., Shaw, G., Andrews, E., Dutton, E. G., RuohoAirola, T., and Gong, S. L.: Arctic haze: current trends and knowledge gaps, Tellus. B, 59, 99-114, doi:10.1111/j.16000889.2006.00238.x, 2007.

Quinn, P. K., Bates, T. S., Baum, E., Doubleday, N., Fiore, A. M., Flanner, M., Fridlind, A., Garrett, T. J., Koch, D., Menon, S., Shindell, D., Stohl, A., and Warren, S. G.: Short-lived pollutants in the Arctic: their climate impact and possible mitigation strategies, Atmos. Chem. Phys., 8, 1723-1735, doi:10.5194/acp8-1723-2008, 2008.

Reddy, M. S. and Boucher, O.: A study of the global cycle of carbonaceous aerosols in the LMDZT general circulation model, J. Geophys. Res.-Atmos., 109, D14202, doi:10.1029/2003JD004048, 2004.

Reid, J. S., Koppmann, R., Eck, T. F., and Eleuterio, D. P.: A review of biomass burning emissions part II: intensive physical properties of biomass burning particles, Atmos. Chem. Phys., 5, 799825,2005 ,

http://www.atmos-chem-phys.net/5/799/2005/.

Reid, J. S., Hyer, E. J., Prins, E. M., Westphal, D. L., Zhang, J. L., Wang, J., Christopher, S. A., Curtis, C. A., Schmidt, C. C., Eleuterio, D. P., Richardson, K. A., and Hoffman, J. P.: Global monitoring and forecasting of biomass-burning smoke: description of and lessons from the fire locating and modeling of burning emissions (FLAMBE) program, IEEE J. Sel. Top. Appl., 2, 144-162, doi:10.1109/JSTARS.2009.2027443, 2009.

Ricard, V., Jaffrezo, J. L., Kerminen, V. M., Hillamo, R. E., Sillanpaa, M., Ruellan, S., Liousse, C., and Cachier, H.: Two years of continuous aerosol measurements in northern Finland, J. Geophys. Res.-Atmos., 107, 4129, doi:10.1029/2001JD000952, 2002.

Rosen, H., Novakov, T., and Bodhaine, B. A.: SOOT IN THE ARCTIC, Atmos. Environ., 15, 1371-1374, doi:10.1016/00046981(81)90343-7, 1981.

Schnell, R. C.: Arctic Haze and the Arctic Gas and Aerosol Sampling Program (Agasp), Geophys. Res. Lett., 11, 361-364, 1984

Sharma, S., Andrews, E., Barrie, L. A., Ogren, J. A., and Lavoue, D.: Variations and sources of the equivalent black carbon in the high Arctic revealed by long-term observations at Alert and Barrow: 1989-2003, J. Geophys. Res.-Atmos., 111, D14208, doi:10.1029/2005JD006581, 2006.

Shaw, G. E.: Evidence for a central eurasian source area of arctic 
haze in alaska, Nature, 299, 815-818, 1982.

Shaw, P. M., Russell, L. M., Jefferson, A., and Quinn, P. K.: Arctic organic aerosol measurements show particles from mixed combustion in spring haze and from frost flowers in winter, Geophys. Res. Lett., 37, L10803, doi:10.1029/2010GL042831, 2010.

Shindell, D. T., Chin, M., Dentener, F., Doherty, R. M., Faluvegi, G., Fiore, A. M., Hess, P., Koch, D. M., MacKenzie, I. A., Sanderson, M. G., Schultz, M. G., Schulz, M., Stevenson, D. S., Teich, H., Textor, C., Wild, O., Bergmann, D. J., Bey, I., Bian, H., Cuvelier, C., Duncan, B. N., Folberth, G., Horowitz, L. W., Jonson, J., Kaminski, J. W., Marmer, E., Park, R., Pringle, K. J., Schroeder, S., Szopa, S., Takemura, T., Zeng, G., Keating, T. J., and Zuber, A.: A multi-model assessment of pollution transport to the Arctic, Atmos. Chem. Phys., 8, 5353-5372, 2008, http://www.atmos-chem-phys.net/8/5353/2008/.

Spackman, J. R., Gao, R. S., Neff, W. D., Schwarz, J. P., Watts, L. A., Fahey, D. W., Holloway, J. S., Ryerson, T. B., Peischl, J., and Brock, C. A.: Aircraft observations of enhancement and depletion of black carbon mass in the springtime Arctic, Atmos. Chem. Phys., 10, 9667-9680, doi:10.5194/acp-10-9667-2010, 2010.

Stith, J. L., Twohy, C. H., DeMott, P. J., Baumgardner, D., Campos, T., Gao, R., and Anderson, J.: Observations of ice nuclei and heterogeneous freezing in a western pacific extratropical storm, Atmos. Chem. Phys., 11, 6229-6243, doi:10.5194/acp-11-62292011, 2011.

Stohl, A.: Characteristics of atmospheric transport into the Arctic troposphere, J. Geophys. Res.-Atmos., 111, D11306, doi:10.1029/2005JD006888, 2006.

Stohl, A., Berg, T., Burkhart, J. F., Fj?raa, A. M., Forster, C., Herber, A., Hov, Ø., Lunder, C., McMillan, W. W., Oltmans, S., Shiobara, M., Simpson, D., Solberg, S., Stebel, K., Strm, J., Trseth, K., Treffeisen, R., Virkkunen, K., and Yttri, K. E.: Arctic smoke - record high air pollution levels in the European Arctic due to agricultural fires in Eastern Europe in spring 2006, Atmos. Chem. Phys., 7, 511-534, doi:10.5194/acp-7-511-2007, 2007.

Stone, R. S., Herber, A., Vitale, V., Mazzola, M., Lupi, A., Schnell, R. C., Dutton, E. G., Liu, P. S. K., Li, S. M., Dethloff, K., Lampert, A., Ritter, C., Stock, M., Neuber, R., and Maturilli, M.: A three-dimensional characterization of Arctic aerosols from airborne Sun photometer observations: PAM-ARCMIP, April 2009, J. Geophys. Res., 115, D13203, doi:10.1029/2009jd013605, 2010.

Targino, A. C., Coe, H., Cozic, J., Crosier, J., Crawford, I., Bower, K., Flynn, M., Gallagher, M., Allan, J., Verheggen, B., Weingartner, E., Baltensperger, U., and Choularton, T.: Influence of particle chemical composition on the phase of cold clouds at a high-alpine site in Switzerland, J. Geophys. Res.-Atmos., 114, D18206, doi:10.1029/2008JD011365, 2009.

Textor, C., Schulz, M., Guibert, S., Kinne, S., Balkanski, Y., Bauer, S., Berntsen, T., Berglen, T., Boucher, O., Chin, M., Dentener, F., Diehl, T., Easter, R., Feichter, H., Fillmore, D., Ghan, S., Ginoux, P., Gong, S., Grini, A., Hendricks, J., Horowitz, L., Huang, P., Isaksen, I., Iversen, I., Kloster, S., Koch, D., Kirkevåg, A., Kristjansson, J. E., Krol, M., Lauer, A., Lamarque, J. F., Liu, X., Montanaro, V., Myhre, G., Penner, J., Pitari, G., Reddy, S., Seland, Ø., Stier, P., Takemura, T., and Tie, X.: Analysis and quantification of the diversities of aerosol life cycles within AeroCom, Atmos. Chem. Phys., 6, 1777-1813, doi:10.5194/acp-6-
1777-2006, 2006.

Tilmes, S., Emmons, L. K., Law, K. S., Ancellet, G., Schlager, H., Paris, J.-D., Fuelberg, H. E., Streets, D. G., Wiedinmyer, C., Diskin, G. S., Kondo, Y., Holloway, J., Schwarz, J. P., Spackman, J. R., Campos, T., Ndlec, P., and Panchenko, M. V.: Source contributions to Northern Hemisphere CO and black carbon during spring and summer 2008 from POLARCAT and START08/preHIPPO observations and MOZART-4, Atmos. Chem. Phys. Discuss., 11, 5935-5983, doi:10.5194/acpd-115935-2011, 2011.

Turpin, B. J. and Lim, H. J.: Species contributions to PM2.5 mass concentrations: Revisiting common assumptions for estimating organic mass, Aerosol Sci. Tech., 35, 602-610, 2001.

van der Werf, G. R., Randerson, J. T., Giglio, L., Collatz, G. J., Kasibhatla, P. S., and Arellano Jr., A. F.: Interannual variability in global biomass burning emissions from 1997 to 2004, Atmos. Chem. Phys., 6, 3423-3441, doi:10.5194/acp-6-3423-2006, 2006

van Donkelaar, A., Martin, R. V., Leaitch, W. R., Macdonald, A. M., Walker, T. W., Streets, D. G., Zhang, Q., Dunlea, E. J., Jimenez, J. L., Dibb, J. E., Huey, L. G., Weber, R., and Andreae, M. O.: Analysis of aircraft and satellite measurements from the Intercontinental Chemical Transport Experiment (INTEX-B) to quantify long-range transport of East Asian sulfur to Canada, Atmos. Chem. Phys., 8, 2999-3014, doi:10.5194/acp-8-2999-2008, 2008.

Volkamer, R., Jimenez, J. L., San Martini, F., Dzepina, K., Zhang, Q., Salcedo, D., Molina, L. T., Worsnop, D. R., and Molina, M. J.: Secondary organic aerosol formation from anthropogenic air pollution: Rapid and higher than expected, Geophys. Res. Lett., 33, L17811, doi:10.1029/2006g1026899, 2006.

Wang, Y. H., Jacob, D. J., and Logan, J. A.: Global simulation of tropospheric $\mathrm{O}_{3}-\mathrm{NO}_{\mathrm{x}}$-hydrocarbon chemistry 1 . Model formulation, J. Geophys. Res.-Atmos., 103, 10713-10725, 1998.

Warneke, C., Bahreini, R., Brioude, J., Brock, C. A., de Gouw, J. A., Fahey, D. W., Froyd, K. D., Holloway, J. S., Middlebrook, A., Miller, L., Montzka, S., Murphy, D. M., Peischl, J., Ryerson, T. B., Schwarz, J. P., Spackman, J. R., and Veres, P.: Biomass burning in Siberia and Kazakhstan as an important source for haze over the Alaskan Arctic in April 2008, Geophys. Res. Lett., 36, L02813, doi:10.1029/2008GL036194, 2009.

Warneke, C., Froyd, K. D., Brioude, J., Bahreini, R., Brock, C. A., Cozic, J., de Gouw, J. A., Fahey, D. W., Ferrare, R., Holloway, J. S., Middlebrook, A. M., Miller, L., Montzka, S., Schwarz, J. P., Sodemann, H., Spackman, J. R., and Stohl, A.: An important contribution to springtime Arctic aerosol from biomass burning in Russia, Geophys. Res. Lett., 37, L01801, doi:10.1029/2009GL041816, 2010.

Warren, S. G. and Wiscombe, W. J.: Dirty snow after nuclear-war, Nature, 313, 467-470, 1985.

Wesely, M. L.: Parameterization of surface resistances to gaseous dry deposition in regional-scale numerical-models, Atmos. Environ., 23, 1293-1304, 1989.

Zhang, Q., Jimenez, J. L., Canagaratna, M. R., Allan, J. D., Coe, H., Ulbrich, I., Alfarra, M. R., Takami, A., Middlebrook, A. M., Sun, Y. L., Dzepina, K., Dunlea, E., Docherty, K., DeCarlo, P. F., Salcedo, D., Onasch, T., Jayne, J. T., Miyoshi, T., Shimono, A., Hatakeyama, S., Takegawa, N., Kondo, Y., Schneider, J., Drewnick, F., Borrmann, S., Weimer, S., Demer- 
jian, K., Williams, P., Bower, K., Bahreini, R., Cottrell, L., Griffin, R. J., Rautiainen, J., Sun, J. Y., Zhang, Y. M., and Worsnop, D. R.: Ubiquity and dominance of oxygenated species in organic aerosols in anthropogenically-influenced Northern Hemisphere midlatitudes, Geophys. Res. Lett., 34, L13801, doi:10.1029/2007GL029979, 2007.

Zhang, L., Jacob, D. J., Boersma, K. F., Jaffe, D. A., Olson, J. R., Bowman, K. W., Worden, J. R., Thompson, A. M., Avery, M. A., Cohen, R. C., Dibb, J. E., Flock, F. M., Fuelberg, H. E., Huey, L. G., McMillan, W. W., Singh, H. B., and Weinheimer, A. J.:
Transpacific transport of ozone pollution and the effect of recent Asian emission increases on air quality in North America: an integrated analysis using satellite, aircraft, ozonesonde, and surface observations, Atmos. Chem. Phys., 8, 6117-6136, doi:10.5194/acp-8-6117-2008, 2008a.

Zhang, X. Y., Wang, Y. Q., Zhang, X. C., Guo, W., and Gong, S. L.: Carbonaceous aerosol composition over various regions of China during 2006, J. Geophys. Res.-Atmos., 113, D14111, doi:10.1029/2007JD009525, 2008b. 